\title{
Insulin-like Growth Factor Binding Proteins and their Role in Controlling IGF Actions
}

\section{David R Clemmons}

The insulin-like growth factor binding proteins (IGFBPs) are a family of six proteins that bind to insulin-like growth factor-I and -II with very high affinity. Because their affinity constants are between two- and 50-fold greater than the IGF-I receptor, they control the distribution of the IGFs among soluble IGFBPs in interstitial fluids, IGFBPs bound to cell surfaces or extracellular matrix (ECM) and cell surface receptors. Although there are six forms of insulin-like growth factor binding proteins, most interstitial fluids contain only three or four forms, and usually only one or two predominate. The proteins differ significantly in their biochemical characteristics, and this accounts for many of the differences that have been observed in their biological actions. Several different types of protease cleave these binding proteins. Proteolytic cleavage generally inactivates the binding proteins or reduces their ability to bind to IGF-I or -II substantially. Several cell types have been shown to secrete these proteases; therefore, the factors that regulate protease activity can control binding protein actions indirectly. Other post-translational modifications, such as glycosylation and phosphorylation, have been shown to alter IGF binding protein activity. While binding protein actions have been studied extensively in vitro, many of the in vivo activities of these proteins remain to be defined. , 1997 Elsevicr Science Ltd. All rights rescrved

Key words: Insulin-like growth factor-I or -II (IGF-I or -II) - IGF binding proteins (IGFBPs) - Growth hormone $(\mathrm{GH}) \cdot \mathrm{IGF}$ receptors $\cdot$ IGFBP proteases $\cdot$ Serine and matrix metalloproteases

The insulin-like growth factor binding proteins (IGFBPs) were originally discovered while attempting to purify insulin-like growth factor-I (IGF-I) from serum [1, 2]. Chromatographic studies showed that most of the IGFI in serum had a molecular weight estimate of $150 \mathrm{kDa}$ by neutral gel filtration chromatography, even though the purified material was later discovered to have a molecular weight of 7649 . This difference was suspected to be due to binding protein activity since acid gel filtration chromatography resulted in dissociation of the IGF biological activity from higher molecular weight proteins [2]. Later, reconstitution experiments showed that the IGF-binding protein complex could reform if the acid gel filtration separated fractions were recombined [3]. This led to attempts to purify the binding activity from serum and amniotic fluid.

Department of Medicine, University of North Carolina, School of Medicine, CB \#7170, Chapel Hill, NC 27599, U.S.A. Tel.: (919) 966-4735; Fax: (919) 966-6025.
The nomenclature used to name the IGF binding proteins was developed as a result of the historical order in which these sequences were identified. IGFBP-1 was the first to be purified and sequenced because of its abundance in amniotic fluid $[4,5]$. This was followed by DNA sequencing which was used to determine the entire amino acid sequence $[6,7]$. The cloning and sequencing of rat IGFBP-2 followed shortly thereafter [8]. IGFBP-3, which had been purified to homogeneity from serum [9], was cloned and sequenced [10]. Subsequently, Ling and coworkers reported the sequences of IGFBP-4, -5 and -6 [11].

During attempts to purify these materials, specific antisera for IGFBP-1 and -3 were developed that allowed the measurement of these proteins in physiological fluids [12. 13]. Subsequently, the development of cDNA probes and antibodies for all six binding proteins further facilitated work in this area. This has led to the rapid accumulation of information regarding the factors that control their synthesis, secretion and distribution among tissues as well as target cell actions [14]. 
CONTROL OF IGF BINDING PROTEIN SYNTHESIS AND SECRETION

The factors that regulate IGF binding protein synthesis by specific cell types are major determinants of the tissue distribution of IGF-I and -II. Both IGF-I and IGF-II have important autocrine/paracrine actions, particularly during fetal life [15] and during tissue repair after injury [16]. Gene targeting experiments have shown that reduced expression of pituitary growth hormone results in dwarfism in mice and that restoration of IGF-I secretion by transgenic manipulation can restore normal growth [17]. Similarly, gene targeting IGF-I of IGF-II results in $40-50 \%$ reduction in size at birth [18], and IGF-I deletion also results in further postnatal growth attenuation [19]. A large percentage of this reduction is believed to be due to the loss of the autocrine or paracrine actions of the IGFs within tissues; therefore, the factors that control tissue IGF concentrations are important for normal growth.

Although all cells and tissues that have been examined synthesize at least one form of IGFBP, the general pattern is that each tissue or cell type synthesizes different combinations. Therefore, mesenchymal cells, such as fibroblasts, synthesize IGFBP-3, -4 and -5 [20], whereas epithelial cells usually synthesize more IGFBP-2 and -4 . Similarly, within organs, there may be discrete regions that localize specific forms of IGFBPs such as, localization of IGFBP-5 within the olfactory bulb [21]. The exact physiological significance of such discreet regional specificity has not been determined. The regulation of synthesis of IGFBPs by specific cell types has been studied intensely and is beyond the scope of this review. An excellent summary of this information is a comprehensive review by Rechler [22].

Generally, IGFBP secretion by cells in culture has been analysed using the technique known as ligand blotting [23]. Some authors have studied synthesis using metabolic labeling and immunoprecipitation [24] and other investigators have studied the effect of various factors on mRNA abundance, mRNA stability or direct analyses of gene transcription [25-27]. In general, these studies have been successful in identifying many factors that stimulate synthesis of individual forms of binding proteins, and there are multiple examples of factors such as retinoic acid that are potent stimuli of synthesis of one particular protein but have no effect on synthesis of another form that is constitutively synthesized by the same cell type [28].

\section{TISSUE EXPRESSION OF IGFBPS}

Analysis of mid-gestational rats has shown that IGFBP-1 expression is restricted to the liver [29]. In contrast, IGFBP-2 expression is very high in tissue types derived from ectoderm and endoderm, but there is very little mesodermal expression. IGFBP-3 expression occurs primarily in mesoderm, but it is restricted to a specific subset of mesenchymal cells. Its expression pattern is complementary to that of IGF-II [30]. In contrast, IGFBP-4 is found to be widely expressed in multiple subsets of mesenchymal cells. IGFBP-5 is expressed as early as day 10 in specific regions of surface ectoderm, in muscle all precursors and differentiating somites, notochord and the foreplate regions of neuroepithelium [30]. Likewise, specific neuronal populations, such as the olfactory bulb, also express this form of IGFBP. Expression of IGFBP-6 does not begin until day 15. It is localized to cells surrounding developing cartilage.

Expression of IGFBPs changes quite significantly in many tissues during the fetal to adult transition. IGFBP2 mRNA is abundant in late fetal rate liver but is extremely low in adult rat liver [22]. In contrast, IGFBP4 mRNA, which is low in the fetal liver, increases substantially in the adult. The converse is true for kidney wherein it is expressed in fairly high levels in the fetus, but undetectable in the adult. The developmental changes in cell-type specific expression of IGFBP-5 have been extremely well characterized in brain, kidney and ovary. The functional consequences of these changes have not been determined.

\section{CONTROL OF IGFBP CONCENTRATIONS IN BLOOD AND REGULATION OF THE ENDOCRINE ACTIONS OF IGF-I AND -II}

The endocrine actions of IGF-I and -II are also necessary for normal postnatal growth and development. Secretion of IGF-I and -II by the liver into the circulation is under the control of pituitary growth hormone, and this is believed to be the origin of the IGFs in the circulation. Ablation of this source by hypophysectomy or GH receptor mutations results in decreased IGF-I mRNA in liver and growth retardation [31,32]. Since, following the entry into the circulation, the IGFs immediately bind to IGFBPs, the factors that control IGFBP concentrations in blood are also potential endocrine regulators of IGF actions. In order to understand the endocrine actions of both IGF-I and -II, it is necessary to understand the role of traditional hormones in controlling IGFBP synthesis by the liver and their secretion into the circulation.

\section{IGFBP-1, -2 and -3}

The principal carrier of IGF-I and -II in serum is IGFBP-3 [33]. It is synthesized in the liver, by nonparenchymal cells [34]. The endothelium may also be an important source [35]. Because of its high affinity constant which is 10 - to 20 -fold greater than either IGFBP1 or -2 , the other major forms of IGFBPs in serum (Table 1), it binds $90-96 \%$ of IGF-I and -II. Its molar concentration is usually nearly equal to the sum of IGF-I plus IGF-II. The blood concentrations of IGFBP-3 are regulated by age, nutrition and the hormonal milieu [36]. Growth hormone $(\mathrm{GH})$ is the major hormonal factor controlling its concentration. Plasma IGFBP-3 levels are elevated in patients with acromegaly, and low in patients with hypopituitarism. GH directly stimulates IGFBP-3 
Table 1. Post-translational modifications

\begin{tabular}{|c|c|c|c|c|c|c|}
\hline $\begin{array}{l}\text { Structural } \\
\text { characteristics }\end{array}$ & IGFBP-1 & IGFBP-2 & IGFBP-3 & IGFBP-4 & IGFBP-5 & IGFBP-6 \\
\hline Glycosylation & - & - & $\mathrm{N}$ & $\mathrm{N}$ & $\mathrm{O}$ & $\mathrm{O}$ \\
\hline Heparin binding & - & $+{ }^{*}$ & + & - & + & ND \\
\hline Phosphorylation & + & - & + & - & + & ND \\
\hline Proteolysis & - & + & + & + & + & ND \\
\hline Cell surface ECM localization & - & + & + & - & + & - \\
\hline RGD sequence & + & + & - & - & - & - \\
\hline
\end{tabular}

"Only if IGF-I or IGF-II is present.

ND: not determined.

synthesis, and factors that attenuate growth hormone action result in a major decrease in its concentration in blood. IGF-I is a secondary regulator and has been reported to increase IGFBP-3 blood concentrations in rodents [22]. However, the effects of IGF-I are complex because it allows binding of a third protein, termed acid labile subunit (ALS) to the IGFBP-3/IGF complex [37]. This acts to stabilize the IGF-I/IGFBP-3 complex and prolong its half life, but whenever IGF-I concentrations exceed the IGFBP-3 binding capacity, they act indirectly (see below) to suppress ALS. Therefore, the role of IGFI appears to be maintenance of IGFBP-3 concentrations.

Hormones other than $\mathrm{GH}$ also influence the synthesis and secretion of IGFBP-3 $[22,31]$, which is low in prepubertal males and is increased following testosterone administration. IGFBP- 3 concentrations are $40 \%$ lower following menopause and can be increased to premenopausal levels in postmenopausal females with physiologic estrogen administration. Thyroxine controls IGFBP-3 concentrations, which are low in primary hypothyroidism and increase to approximately $55 \%$ following adminstration of thyroxine. Insulin may have a role in maintaining plasma IGFBP-3 concentration, since it improves the IGFBP-3 synthesis response to GH, but it does not appear to have a direct effect.

Coordinate regulation of IGF-I and IGFBP-3 is an important mechanism for maintaining an adequate reservoir of IGF-I in the vasculature. When IGF-I synthesis is increased by $\mathrm{GH}$, there is a concomitant increase in IGFBP-3 and therefore in IGF binding capacity. In addition to these two proteins, the IGF/IGFBP-3 complex binds to the acid labile subunit, and these three proteins constitute the stable $150,000-\mathrm{Da}$ ternary complex. The synthesis secretion of ALS is dependent upon GH and it is not increased by IGF-I. However, since IGF-I or IGF-II binding to IGFBP-3 facilitates its binding to ALS, an increase in IGF-I will act to stabilize the three proteins and prolong their half-lives [38].

GH directly stimulates ALS synthesis in hepatocytes [39]. A major function of the IGFBP-3/ALS complex is to prolong the half lives of IGF-I and -II in the vasculature. ALS functions to attenuate transport of the binary IGF/IGFBP-3 complex out of the vasculature. While free IGFBP-3 is cleared from serum with a half-life of $1-2 \mathrm{~h}$, the ALS/IGFBP-3/IGF complex has a half-life of $16 \mathrm{~h}$
[40]. This results in retention of the IGFBP-3 that is contained within the complex and reduces the clearance rate of the IGFs. In general, most of the IGF-I and -II $(>90 \%)$ in serum is bound to this complex, although some IGF is present bound to IGFBP-3 that is not associated with the complex and to other forms of IGFBPs. Although IGF-I can also stimulate an increase in IGFBP3 , free IGF-I suppresses GH which is necessary to maintain normal ALS levels. Therefore, high dose administration of IGF-I will result in decreased ALS and ultimately in decreased levels of IGFBP-3. This results in a smaller pool of plasma IGF and an attenuated response in terms of protein synthesis and protein balance. Animals that are treated with $\mathrm{GH}$ intravenously show a two-fold increase in ALS concentrations, and a four-fold increase in ALS mRNA [39]. Severe insulin depletion results in decreased ALS synthesis, possibly leading to the reduction in serum IGF-I levels seen in diabetes, and insulin is necessary for hepatocytes to maintain normal ALS synthesis in vitro. Glucocorticoids suppress ALS mRNA synthesis and fasting results in a decrease in ALS concentrations $[39,41]$. Therefore, ALS appears to be regulated parallel with IGFBP-3 and to some extent with IGF-I.

In summary, several factors function coordinately to maintain near equimolar concentrations of the sum of IGF-I, plus IGF-II with IGFBP-3. These include rapid clearance of free IGF, a coordinate increase in the synthesis of IGF-I, IGFBP-3 and ALS in response to GH and maintenance of the ternary complex by IGF-I or IGF-II binding. Although binary complexes of IGF-I or IGF-II and IGFBP-3 form in the serum, they constitute a small percentage of the total IGF concentration.

IGFBP-2 is the second most abundant form of IGFBP in serum. Its affinity for IGF-II is four-fold higher than its affinity for IGF-I. This protein does not form a ternary complex with any other protein and circulates associated in a binary complex with either IGF-I or IGF-II [42]. This complex has a molecular weight estimate of 40 $50 \mathrm{kDa}$. The IGFBP-2 that is present in the circulation originates from hepatocytes, and the abundance of IGFBP-2 mRNA in liver is regulated in parallel with its plasma concentrations. GH is a determinant of IGFBP2 plasma concentrations, and they are inversely related to the ambient level of GH. IGF-I is a potent stimulant of 
IGFBP-2 concentrations in serum [43]. Generally, there is an excess of IGFBP-2 binding capacity in serum, and, therefore, it can act as a reservoir for free IGF-I following acute IGF-I administration. Plasma IGFBP-2 concentrations also appear to be increased by IGF-II, particularly in patients with non-islet cell tumor hypoglycemia (tumors that produce IGF-II) [44].

Hepatic IGFBP-2 mRNA expression is increased significantly in diabetic rats and suppressed with insulin administration [45]. This finding is not mimicked in humans, however, who show no significant increases in serum IGFBP-2 concentrations unless they are also severely malnourished, and IGFBP-2 levels are not acutely suppressed in patients with Type I diabetes by insulin. Nutrition is a weak regulator of IGFBP-2 expression. IGFBP-2 gene transcription is increased in starved rodents and plasma concentrations are increased in fasted humans [46]. This change is slow, and it takes 6 days for levels to reach their maximum. The principal nutrient that appears to be involved is protein since moderate caloric restriction in normal human subjects does not result in any significant change in IGFBP-2 concentrations, but severe protein deprivation results in a 30 $40 \%$ increase. Strauss et al. have shown that the hepatic IGFBP-2 mRNA increases with protein restriction, and this change is reversible with protein refeeding [47].

IGFBP-2 has also been shown to be regulated by thyroxine. Thyroxine administration to hypothyroid animals results in a small increase in IGFBP-2. Data with sex steroids, such as androgens, have not been reported. Glucocorticoids suppress IGFBP-2 synthesis in mesenchymal cells, but have minimal effects on serum IGFBP-2 levels.

GH regulation of IGFBP-2 has been demonstrated in experimental animals. Hypophysectomy in rats results in a 10- to 20-fold increase in IGFBP-2 mRNA in the liver, and plasma levels are also concomitantly increased [25]. Similarly, hypophysectomy in pigs results in a substantial increase. Insulin deficiency also results in an increase in plasma IGFBP-2 in rats, and readministration of insulin to diabetic animals results in a decrease. However, humans with poorly controlled Type I diabetes do not have an increase in plasma IGFBP-2. GH administration to humans results in a substantial lowering of plasma IGFBP-2 [46]. The effect of GH appears to be mediated independently of insulin. That this is a direct effect of $\mathrm{GH}$ is suggested by the observation that administration of $\mathrm{GH}$ to patients with $\mathrm{GH}$ receptor mutations does not result in such a decrease [32].

The IGFBP-1 that is present in the circulation is also synthesized in the liver. In situ hybridization studies have shown that the liver, maternal placenta and uterus are the only major sites of synthesis [22]. Hepatic synthesis of IGFBP-1 is primarily under the control of insulin, although other hormones such as $\mathrm{GH}$ and cortisol also participate. In contrast to IGFBP-3, a substantial portion of IGFBP-1 and -2 in blood is unsaturated. Therefore, they have been postulated to be the major modulators of free IGF levels. Insulin is the major determinant of plasma IGFBP-1 concentrations. The post-prandial increase that occurs in serum insulin concentrations results in a four- to five-fold decrease in IGFBP-1 [48]. This change is due to a direct suppression of IGFBP-1 synthesis in the liver [48]. IGFBP-1 mRNA abundance in liver has been shown to decrease after administration of insulin to diabetic or normal animals. This change is due to direct effect of IGFBP-1 transcription, and there is an insulin response element in the $5^{\prime}$ flanking region of the IGFBP-1 gene [49]. This element has a consensus sequence that is similar to the insulin response element in the PEPCK gene and mediates the effect of insulin on transcription [50]. IGFBP-1 has also been shown to cross intact capillary beds, and the amount that crosses in a fixed time period is dependent upon the ambient insulin concentration [51]. This provides a second mechanism by which insulin can decrease serum IGFBP-1. The functional consequences of this large change in IGFBP-1 on IGF-I stimulated glucose disposal are not well defined. Lewitt et al. showed that acute administration of a large excess of IGFBP-1 to normal rats resulted in a slight increase in blood glucose [52]. However, the manner in which this protein functions in the usual physiological situation where there is a relatively low concentration of unsaturated IGFBP-1 (e.g. only enough to bind 2-5 $\mathrm{ng} / \mathrm{ml}$ of IGF-I) is not entirely clear.

In addition to decreasing after insulin administration, IGFBP-1 levels also correlate with changes in insulin sensitivity. IGFBP-1 levels are elevated in Type I diabetes and are lowered after administration of insulin. Fasting for relatively short periods, e.g. $12-14 \mathrm{~h}$, results in a fourto six-fold increase in IGFBP-1 concentrations, probably due to suppression of insulin [46]. In states of insulin resistance, IGFBP-1 levels are elevated but return to normal when these states are ameliorated. GH suppresses IGFBP-1, and its levels are elevated in children or adults with $\mathrm{GH}$ deficiency $[48,53]$.

In addition to insulin, glucocorticoids that are counterregulatory hormones opposing insulin action have the opposite effect on IGFBP-1 synthesis. Specifically, glucocorticoid administration to animals results in increased serum IGFBP-1 concentrations $[54,55]$. In cell culture, IGFBP-1 gene transcription has been shown to be directly enhanced by glucocorticoid addition, and insulin reverses this effect in a dominant negative manner [24]. More recently, a glucocorticoid response element in the 5 'flanking region of the IGFBP-1 gene has been identified [49]. In addition, there is direct interaction between insulin and glucocorticoids in regulating IGFBP-1 transcription. Glucocorticoid-mediated induced IGFBP-1 transcription is also dependent upon hepatic nuclear factor 3 (HNF-3) and an intact HNF sequence is required for glucocorticoids to stimulate and for insulin to inhibit IGFBP-1 promoter activity [56]. Thus, plasma levels of IGFBP-1 appear to be regulated predominantly at the level of hepatic mRNA synthesis. The exact role by which these hormonally induced changes in IGFBP-1 modify IGF-I and -II actions to alter carbohydrate metabolism requires further analysis. 
boxyl terminal ends, have some IGF binding activity

The serum concentrations of intact IGFBP-4 are quite low, and the role of this peptide in regulating IGF bioavailability from vascular sources in unclear. The only major hormone that has been shown to regulate IGFBP4 concentrations in serum is the parathyroid hormone. Mohan and coworkers showed that, in states of low bone turnover and low parathyroid hormone concentrations, serum IGFBP-4 concentrations were increased [57]. Similarly, other investigators have shown some correlation with sunlight exposure suggesting that vitamin $D$ or one of its active metabolites also may regulate serum IGFBP4. Since IGFBP-4 is a potent inhibitor of IGF acitivty in bone, this suggests that serum IGFBP-4 concentrations may be linked to the control of the trophic effects of IGFI on bone metabolism.

Studies to determine the variables that regulate the serum concentrations of IGFBP-5 and -6 are limited. Although these proteins are detectable in serum, their concentrations are extremely low, and it is difficult, at this time from the available published data, to present an organized theory as to how changes in their serum concentrations might alter IGF action. Additionally, IGFBP-5 is synthesized principally by connective tissues, and the protein has several characteristics (to be reviewed below) that inhibit its ability to enter the vascular space.

\section{PROTEIN STRUCTURES AND FUNCTIONAL RELATIONSHIPS}

The amino acid sequences of the six forms of IGF binding proteins are shown in Figure 1. Analysis of the sequence alignment of these proteins shows several common and yet distinct structural features. Each protein contains a leader sequence with a hydrophobic domain, and all are known to be synthesized and secreted by at least one cell type. The proteins vary in length from 216 amino acids (IGFBP-6) to 289 amino acids (IGFBP-2). All six proteins contain 18 cysteines that are conserved. IGFBP-4 contains two additional cysteines in the central core of the molecule. There is a great deal of conservation of sequence in both the amino and carboxyl terminal regions. The region containing the first 10 cysteines in the amino terminal domain is highly conserved. In the region between cysteines 5 and 11,21 and 29 amino acids are conserved in five of the six proteins. The region between cysteines 12 and 18 is also conserved. The region between cysteines 14 and 17 contains 17 of 28 amino acids that are identical in at least five of the six forms of IGFBPs. Although the exact linear sequences responsible for IGF binding have not been identified, it is presumed that a combination of these conserved sequences plus a specific folding pattern is required for IGF recognition. Data to support this conclusion include experiments in which the disulfides have been reduced and then scrambled. These altered forms bind IGF-I poorly [58]. Similarly, fragments of the protein that contain intact intrachain disulfide bonds, but only the amino or car-
[59]. Fragments that contain only the cental core of the molecule that is not conserved have no IGF binding activity.

Another conserved element of interest is the Arg-GlyAsp sequence that is located in the carboxyl terminus of IGFBP-1 and -2. IGFBP-1 has been shown to bind to the $\alpha 5 \beta 1$ integrin through this sequence [60]. Radiolabeling of both human fibroblast and porcine aortic smooth muscle cell surface proteins followed by immunoprecipitation with anti-integrin antibodies shows that multiple integrins are present. However, $\alpha 5 \beta 1$ is on the integrin that binds to IGFBP-1. IGFBP-2 does not bind to $\alpha 5 \beta 1$, suggesting that it is folded in such a way that its RGD sequence cannot bind to this integrin.

The central nonconserved region of the IGFBPs also has an important physiological role. All of the IGFBPs are cleaved by proteases, and proteolysis results in the loss of IGF binding affinity. Most of the proteolytic cleavage sites that have been identified to date are within the nonconserved region [61]. Therefore, it is likely that protease specificity is due in part to the presence of these nonconserved sequences. Since distinct proteases have been identified for IGFBP-2, $-3,-4$, and -5 , it is likely that these proteases use unique cleavage sites. This has the potential to provide a physiological mechanism by which the activities of IGFs are regulated in a tissue or cell-type specific manner.

Two IGF-binding proteins, e.g. IGFBP-3 and -4 , have been shown to undergo N-linked glycosylation. IGFBP3 contains three putative $\mathrm{N}$-linked glycosylation sites, of which at least two have been shown to be used. IGFBP4 contains one consensus site which is also used. Both IGFBP-5 and -6 have been shown to be O-glycosylated. The biologic significance of both $\mathrm{O}$ - and $\mathrm{N}$-glycosylation for these proteins is undefined.

\section{VARIABLES THAT REGULATE THE AFFINITIES OF THE VARIOUS FORMS OF IGFBPS}

One of the most important observations regarding IGFBPs is their high affinity for IGF-I and -II. IGFBP3 and -5 have the highest affinity. These estimates vary between being two- and 50 -fold greater than the Type I IGF receptor. The biological implications of this high affinity are obvious since soluble high-affinity IGFBPs will prevent receptor association. The importance of changes in the affinities for IGFBPs is that, under specific situations where their affinities are lowered significantly, they can provide a stable reservoir of IGF that is in a more favorable equilibrium with receptors and, therefore, capable of stimulating growth and anabolic functions. Additionally, they may prevent clearance of IGF from tissues, thereby providing a more stable reservoir. Therefore, it has been of interest to determine the variables that regulate IGFBP affinity.

To date, three factors have been shown to dramatically alter affinity of IGFBPs (Table 1). The first is proteolysis. 

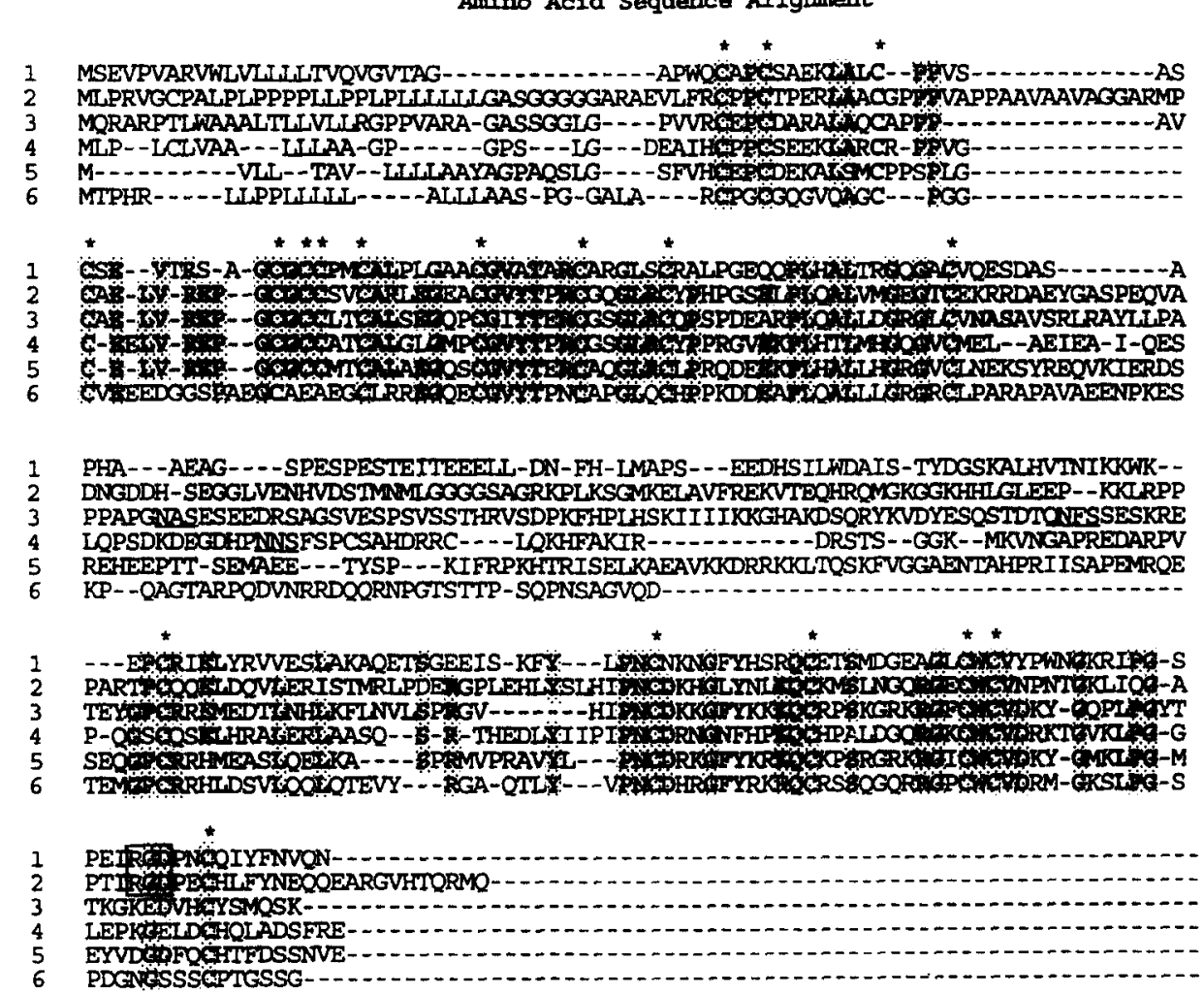

Figure 1. The amino acid sequences of the human IGF binding proteins are shown. The amino acids that are identical in at least four of the six IGFBPs are shaded. The asterisk indicates conserved cysteines. The RGD sequences in the IGFBP-1 and -2 are boxed. The $\mathrm{N}$-glycosylation sites in IGFBP-3 and -4 are underlined.

Although proteolytic cleavage may result in the generation of fragments that have no affinity for IGF, it has also been shown to result in fragments that have significantly lower affinity, and binding to these lower affinity fragments has been shown, in some cases, to result in potentiation of the effect of IGF-I. Similarly, phosphorylation of IGFBP-1 has been shown to increase its affinity for IGF-I by approximately six-fold [62]. The lower affinity nonphosphorylated forms of IGFBP-1 have been shown, under certain culture conditions, to enhance the effect of IGF-I on smooth muscle cell and fibroblast replication [63]. Finally, adherence to either cell surfaces or the extracellular matrix has been shown to be associated with a lowering of IGFBP affinity and potentiation of IGF action [64-66]. Therefore, the variables that regulate the affinity of these proteins may be important determinants of IGF action at the cellular level.

\section{Proteolysis}

The initial studies of IGFBP proteases were directed toward the analysis of IGFBP-3 proteolysis since IGFBP3 is the predominant form in serum. It was shown that a divalent dependent protease activity existed in normal serum, but following proteolysis of the $150 \mathrm{~K}$ complex, IGF-I and -II remained associated with this complex, although the affinity of the IGFBP for IGF-I was reduced [67]. Treatment with heparin (a strong cationic agent) resulted in dissociation, whereas treatment of the non- proteolysed complex did not, suggesting that proteolysis had altered the affinity of IGFBP-3 for IGF-I. Recently, these earlier observations have been clarified by showing that the principal fragment of IGFBP-3, that is the 30 $\mathrm{kDa}$ fragment that is generated, can still bind to IGF-I or IGF-II, but with reduced affinity [68]. This binary complex is still capable of binding to ALS [69].

Subsequently, it was determined that both human and rat pregnancy serum contained high concentrations of a protease that cleaved IGFBP-3 [70-72]. The technique of ligand blotting had been developed at that time, and this technique was used to show that the remaining IGFBP-3 fragments had significantly reduced affinity for IGF-I. Incubation of intact IGFBP-3 with pregnancy serum containing the protease in vitro, followed by immunoblotting, confirmed that the size of IGFBP-3 had shifted protein from 46 to $30 \mathrm{kDa}$. This protease was found to be a cation-dependent serine protease. Subsequent studies have shown that matrix metalloproteases, principally MMP1 and MMP2, which are also present in human and rat pregnancy serum, can degrade IGFBP-3 [73]. Unlike the serine protease activity, these proteases are not specific for IGFBP-3 but will degrade other forms of IGFBPs.

The exact sites of MMP cleavage have not been determined; however, it has been shown that they are in the central core (nonconserved region) of IGFBP-3. Proteolytic activity increases as a function of gestation in the rat, and there is much more activity in the latter part of pregnancy than the first half of pregnancy. In humans, this time-dependent change in IGFBP-3 proteolysis is less 
important, and the activity is high throughout gestation. The change in MMP activity may be due to the decline in tissue inhibitor of metalloprotease that occurs during pregnancy. Plasmin has been proposed to be one of the IGFBP-3 proteases in pregnancy serum [74]. However, free plasmin is not present in plasma, and, therefore, the degradation caused by plasmin would have to occur during placental passage. Although normal plasma contains very little detectable IGFBP-3 protease, proteolytic activity can be detected in a variety of conditions other than pregnancy. In $\mathrm{GH}$ deficiency, there is increased IGFBP-3 protease activity [75]. Likewise, after stresses such as the induction of surgery or acute medical illnesses, there is an increase in proteolytic activity in serum [76, 77]. Fasting induces proteolysis, as does non-insulindependent diabetes.

The consequences of proteolysis of serum IGFBP-3 are less well understood. Since the $30-\mathrm{kDa}$ fragment of IGFBP-3 that is detected has a 20 - to 30 -fold reduction in affinity for IGF-I, it has been proposed that the remaining IGF-I that is bound is in more of a nearly complete equilibrium with the extravascular tissues. Binoux has shown that the IGF-I that is bound to the $150-\mathrm{kDa}$ complex following proteolysis is in much better equilibrium with other binding proteins in serum and the IGFs in extravascular space [78]. This may be an important mechanism for providing IGF to extracellular tissues during times of stress when the protease activity is abundant.

Certain proteases that exist in serum other than plasmin have been shown to degrade IGFBP-3. One is prostate specific antigen (PSA), which is present in high concentrations in patients with disseminated prostate cancer [79]. The other specific protease that degrades IGFBP-3 is Cathepsin-D [80]. However, the role of Cathepsin-D in controlling IGFBP-3 abundance in tissues remains to be established since this is an intracellular cleavage event. Other than the tissue specific localization of the IGFBP-3 pregnancy serum protease activity in placenta, the origin of most IGFBP-3 protease activity has not been determined. Several cell types, including fibroblasts, endothelial cells and breast carcinoma cells in culture have been shown to release proteases that cleave IGFBP-3. The exact identity of most of these proteolytic activities and the variables that control their abundance are unknown at present.

Proteases have been detected in physiologic fluids outside the vascular compartment. Lymph has been shown to contain high concentrations of IGFBP-3 protease [81]. This suggests that proteolysis may occur in interstitial fluids after transport out of the vascular compartment. The activity of IGFBP-3 protease has also been studied in peritoneal fluid, ovarian follicular fluid and synovial fluid. Peritoneal fluid contains the greatest amount of activity [82]. Joint fluid obtained from patients with osteoarthritis or rheumatoid arthritis contains considerably more proteolytic activity compared to normal joint fluid.

Serum has also been shown to contain a protease that cleaves IGFBP-2. This would result in rapid clearance of
IGFBP-2 from the circulation and therefore decrease the half-life of IGF-I. Levels of this protease are increased during starvation [83]. Unlike the IGFBP-3 protease, this activity could not be demonstrated in vitro and is solely an in vivo phenomenon, suggesting that the protease is not released into the serum $[83,84]$. Children with severe protein calorie malnutrition have been shown to have significant cleavage of IGFBP-2 [85]. Food deprivation of new born pigs also results in the appearance of IGFBP2 proteolytic activity in serum [84].

An IGFBP-2 specific serine protease has been shown to be present in culture supernatants of aortic smooth muscle cells [86]. This serine protease is inhibitable with multiple members of the serpin inhibitor family, including heparin cofactor II and anti-thrombin-III. Heparin also directly inhibits the activity of this protease. The effect of these serpins can be potentiated in the presence of heparin. It has a molecular weight estimate of $37 \mathrm{kDa}$. To cleave IGFBP-2 optimally, the protease requires the presence of either IGF-I or IGF-II binding to IGFBP2. If neither is bound to the substrate, then proteolysis proceeds at a very slow rate. The fragments that are generated are identical in size to those that are present in pig serum after starvation, suggesting that the same protease may be accounting for its cleavage. The protease is specific for IGFBP-2 and does not degrade other forms of IGFBPs. The IGFBP-2 fragments that are generated do not have the capacity to bind to either IGF-I or IGFII; therefore, proteolytic cleavage may be necessary for IGF-I and -II to access receptors, although this has not been definitely proven.

Like IGFBP-2 and -3, IGFBP-5 is also proteolytically cleaved [87]. One of the unique properties of IGFBP-5 is its ability to associate with the extracellular matrix (ECM). When associated with the ECM, it appears to be protected from proteolysis. However, when it is present in interstitial fluids, it is degraded. The cell types that have been analysed, e.g. fibroblasts, osteoblasts and smooth muscle cells, release a serine protease into their medium [20, 87, 88]. Like IGFBP-3, IGFBP-5 is also cleaved by MMPs [89]. In fibroblast-conditioned medium, IGFBP5 is degraded both by a serine protease and by MMPs, but the activity of the MMPs is relatively less compared to the serine protease because of the presence of Timp-1 and -2 , which are also synthesized by these cells. The serine protease degrades IGFBP-5 into a major 22-kDa fragment that has a very weak binding affinity for IGF-I and -II. Like the IGFBP-2 protease, this serine protease is inhibited by serpins including anti-thrombin-III, heparin cofactor II and heparin, and its activity can be modulated by these substances in vivo. It has a molecular weight estimate of $95 \mathrm{kDa}$ and is specific for IGFBP-5 [90]. Unlike the IGFBP-2 protease, IGF-I and -II binding to IGFBP-5 does not significantly alter the rate of proteolysis. Since the identity of the protease has not been established, the variables that regulate activity are unknown. However, it is clear that, when there is a high ratio of $I G F B P-5$ to $I G F-I$, a certain rate of proteolysis needs to be maintained in order for IGF-I to stimulate 
cellular responses. The MMPs that degrade IGFBP-5 in vitro include $52-$ and $72-\mathrm{kDa}$ gelatinases. An osteoblast cell line (MC 3T3) that was studied by Thrailkill and coworkers was shown to contain a 97-kDa serine protease activity and two metalloproteases [89]. All three enzymes degraded IGFBP-5.

Proteases for IGFBP-4 are present in several tissue culture fluids, including cell culture supernatants from osteoblasts, neuronal and smooth muscle cells [92-93]. The U2 osteosarcoma cell secretes a protease for IGFBP4. Its activity is inhibited by aprotinin and soybean trypsin inhibitor but also by 1,10-phenathroline and EDTA [94]. The U2 cell protease requires IGF-I binding to IGFBP-4 in order to detect activity. The protease inhibitor data were interpreted to conclude that the U2 condition media contained a metalloprotease. In contrast, porcine aortic smooth muscle cells secrete an IGFBP-4 protease that is specific for IGFBP-4 and does not degrade other forms of IGFBPs. The activity of this protease is also enhanced by IGF-I binding to IGFBP-4 [94]. It is a calcium-dependent, serine protease, and it has an estimated molecular weight of $52 \mathrm{kDa}$.

\section{Phosphorylation of IGFBPs}

Three of the five forms of IGFBPs have been shown to be phosphorylated, specifically IGFBP-1, -3 and -5 . IGFBP-1 is phosphorylated on serine residues at positions 101,119 and 169 by a kinase that is present in CHO cells and HEP-G2 cells. Phosphorylation increases the affinity of IGFBP-1 for IGF-I by six-fold. This probably has some physiological significance since different phosphorylated forms have been found in physiological fluids [62]. In amniotic fluid, most of the IGFBP-1 that is detected is in the nonphosphorylated form, whereas serum from adult animals contains mostly phosphorylated forms. The number of phosphates per IGFBP-1 molecule appears to control the affinity of IGFBP-1 for IGF-I since mutagenesis experiments have shown that mutants that cannot phosphorylate the 101 or 169 positions have significantly reduced affinity [95].

The relative degree of phosphorylation can be detected by nondenaturing PAGE which results in separation of the various phosphoisoforms with different electrophoretic mobilities [62]. IGFBP-1 phosphomutants also have electrophoretic mobilities that correspond to their relative loss of phosphates. The biochemical identity of the kinase that is present in HEP-G2 cells (probably also present in normal hepatocytes) and that phosphorylates IGFBP-1 is unknown. Attempts to purify this material showed that casein kinase II is a candidate enzyme and a kinase with an $M_{\mathrm{r}}$ estimate of $38 \mathrm{kDa}$ that has biochemical properties similar, but not identical to, casein kinase I, was also identified [96]. The hormonal variables that regulate these kinase activities are unknown. White and coworkers have shown that diabetic serum contains a very highly phosphorylated form of IGFBP-1 that has a relatively high affinity for IGF-I and the regulation of
IGFBP-1 phosphorylation in diabetes may be an important determinant of IGF-I action in this particular disorder [97]. IGFBP-3 has also been shown to be phosphorylated, but the relative abundance of phosphorylated forms of IGFBP-3 has not been determined [98]. The phosphorylation sites have been identified at positions 111 and 113, but the identity of the kinase that is responsible for IGFBP-3 phosphorylation and the variables that regulate its activity are undetermined.

\section{Adherence to cell surfaces, extracellular matrix and glycosaminoglycans}

Studies that have determined the effect of adherence to cell surfaces or to ECM on the affinity of IGFBP-3 and 5 for IGF-I have been reported [66, 84]. Both IGFBP-3 and IGFBP-5 have been shown to adhere to cell surfaces. This binding interaction is believed to be mediated for both proteins through proteoglycans. Baxter has shown that proteoglycan binding results in disruption of the IGF/IGFBP-3/ALS complex, thus resulting in a better equilibrium with other carriers or extravascular tissues [99]. However, IGFBP-3 has also been shown to bind to non-proteoglycan-containing proteins on the cell surface, and one group has presented data suggesting that this may be through a specific cell surface receptor. IGFBP5 , in contrast, binds only to a heparin inhibitable cell surface site. Functionally, IGFBP-3 binding to cell surfaces is important because it results in a ten-fold reduction in IGFBP-3 affinity of IGF-I [84], and adherence has been shown to enhance the effect of IGF-I in stimulating AIB uptake by fibroblasts [100].

Similarly, IGF-I that is bound to ECM-associated IGFBP-3 or IGFBP-5 is in a more favorable equilibrium with receptors [66]. IGFBP-5 binding to ECM results in an eight-fold reduction in affinity and is associated with stabilization of the IGFBP-5/IGF complex such that it is resistant to proteolytic cleavage. IGFBP-5 clearly associates with proteoglycans in the ECM; however, other nonproteoglycans containing proteins can also bind IGFBP5. Adherence to proteoglycans results in a major reduction (15-fold) in the affinity of IGFBP-5 for IGF-I, and a modest reduction (three-fold) in the affinity of IGFBP-3 [101]. The eight-fold reduction in IGFBP-5 affinity that occurs after ECM association may be required for IGFBP-5 to potentiate IGF action. IGFBP3 binds poorly to the extracellular matrix (ECM) compared to IGFBP-5, and ECM binding results in a minimal change in affinity. Therefore, ECM and cell surface adherence may be important mechanisms by which the effects of these binding proteins modulate the effects of IGF-I (see below).

\section{MODULATION OF IGF ACTION BY IGFBPS}

The effects of each form of IGFBP and IGF actions have been studied in detail, but most of the studies have been conducted in vitro using cultured cells. Recently, some in vivo studies have been forthcoming as well as one 
significant gene targeting experiment for IGFBP-2. These data have allowed a more comprehensive picture of the role of these proteins in controlling IGF action. Because of their relatively high affinities, the IGF binding proteins have the potential to control the distribution of the IGFs among soluble forms of IGFBPs, the forms of IGFBPs that are bound to either cell surfaces or ECM, and cell surface IGF receptors. In addition, by controlling the rate of efflux from the vascular compartment and the exposure to renal tubular cells, the principal site of IGFI degradation and elimination, they have a direct role in controlling IGF-I bioavailability. Although this review will discuss the individual actions of each protein, since they have usually been studied in isolation, it is important to remember that each cell type synthesizes multiple forms of IGFBPs as well as IGFBP proteases. Therefore, the target actions of any given form of IGFBP are regulated by the abundance of that binding protein, its affinity for IGF-I or IGF-II, the relative concentration of IGF-I and -II within that physiological fluid and the amount of proteolytic activity.

Another variable that is often overlooked is that most cell culture experiments are conducted by removing the conditioned culture medium from the cell cultures at the time of initiation of the experiment, thereby reducing the soluble binding protein levels in the medium to zero, then adding back IGF-I. This is a nonphysiological situation since IGFBPs are present in all interstitial fluids, and, therefore. changes in IGF-I in vivo occur on a background of some concentration of binding protein. Therefore, the use of established culture conditions will artificially increase free IGF-I and will not mimic the usual in vivo pericellular environment.

\section{IGFBP-1}

\section{Inhibition of IGF actions}

Addition of an excess of IGFBP-1 with IGF-I or IGFII will result in inhibition of their actions if certain requirements are met. The form of IGFBP-1 must be highly phosphorylated or it must be added in a molar excess of at least a $4: 1$. In addition, using an assay system, in which the biological response can be quantified after a relatively brief interval, will make it more likely that inhibition will be detected. Thus, excess IGFBP-1 has been shown to inhibit alpha aminoisobutyric acid (AIB) uptake in JEG-3 carcinoma cells and protein synthesis in muscle cells [102]. Likewise, it can inhibit IGF-I stimulated glucose incorporation into Balb/c3T3 fibroblasts [103]. One experiment has shown that IGFBP-1 blocks IGF-I interaction with receptors on human endometrial membranes, suggesting that this is the principal mechanism by which inhibition occurs [104]. Highly phosphorylated forms of IGFBP-1 have been shown to inhibit ${ }^{3} \mathrm{H}$-thymidine incorporation using prolonged incubation times of $24-36 \mathrm{~h}$. Similarly, it inhibits DNA synthesis in FRTL 5 cells, chick pelvic embryo leaflets and chick embryo fibroblasts [105].
Four important in-vivo experiments have been conducted that have shown inhibitory effects of IGFBP-1 (Table 2). Lewitt and coworkers injected a very large concentration of IGFBP-1 that resulted in at least a $10: 1$ excess of IGFBP-1 to free IGF-I into rats [42]. This resulted in a transient increase in blood glucose concentration that had returned to normal at a time when the ratio had decreased to less than $4: 1$. This suggests that, at very high molar ratios, IGFBP-1 can inhibit free IGF-I concentrations sufficiently to reduce the effect of free IGF-I on glucose incorporation. Cox and coworkers injected a molar excess of IGFBP-1 with IGF-I to hypophysectomized rats and achieved some attenuation of IGF-I action in stimulating growth and sulfate incorporation into cartilage [106]. These investigators used the nonphosphorylated form of IGFBP-1, suggesting that, if a high enough molar ratio is used, the phosphorylated form is not required to achieve inhibition. Two experiments, using transgenic animals, have been reported. D'Ercole and coworkers created a transgenic mouse strain in which there was high expression of IGFBP-1 in the brain [107]. Since IGFBP-I is not constitutively synthesized in the brain, this resulted in a pharmacological situation in which there were relatively high concentrations of IGFBP-1 compared to free IGF-I. Under these conditions, brain growth retardation was noted. Interestingly, although the IGFBP-1 levels that were achieved in serum were ten times normal, the animals showed no somatic growth retardation, suggesting that the molar excess of IGFBP-1 to IGF-I in the brain was relatively greater than in the serum. The phosphorylation state of the IGFBP-1 in the brain or in the serum was not determined.

In a separate series of studies. Rajkumar and coworkers used a different promoter and achieved very high IGFBP-1 expression during fetal growth [108]. This promoter was activated very early in fetal life and resulted in high IGFBP-1 levels in fetal tissues. Under these conditions, these investigators achieved a small amount of somatic growth retardation. The levels of IGFBP-I in the serum were markedly elevated. at least tenfold greater than they would have been under normal physiologic conditions. These two experiments illustrate that if in vitro conditions can be mimicked in in vivo models, e.g. extremely high levels of IGFBP-I relative to IGF-I, then growth attenuation can be observed.

\section{Simulation of IGF action}

When experiments are designed to mimic more closely the normal physiological ratio of IGF-I to IGFBP-1, this form of IGFBP can be shown to potentiate the effects of IGF-I. Specifically, when nonphosphorylated forms are added with a molar excess of IGF-I to IGFBP-1 to porcine aortic smooth muscle or human fibroblast cultures there is a 5.5-fold enhancement of the effect of IGF-I on DNA synthesis [63, 109]. Under these conditions, degradation and clearance of IGF-I have been inhibited 
Table 2. IGFBP functions in vivo

\begin{tabular}{lll}
\hline Binding protein & Proposed function & Animal model \\
\hline IGFBP-1 & $\begin{array}{l}\text { Molar excess inhibits IGF growth-promoting actions. } \\
\text { Inhibits insulin-like actions } \\
\text { Enhances IGF-mediated splenic growth }\end{array}$ & $\begin{array}{l}\text { Transgenic mice } \\
\text { Hypophysectomized rats } \\
\text { IGFBP-2 }\end{array}$ \\
$\begin{array}{lll}\text { Enhances IGF-I actions in bone muscle and visceral organ growth } \\
\text { IGFBP-3 }\end{array}$ & $\begin{array}{l}\text { Kajor carrier of IGF-I and IGF-II } \\
\text { Transgenic mice }\end{array}$ \\
IGFBP-4 & Inhibits IGF actions & ND \\
IGFBP-5 & Inhibits or enhances IGF actions depending upon its affinity & ND \\
IGFBP-6 & Localizes IGF-I and -II in ECM & ND \\
\hline
\end{tabular}

ND: not determined.

and the affinity of the binding protein is low enough that it approximates that of the receptor, thus allowing material that is bound to IGF to remain in equilibrium with receptors for a prolonged interval. Since a 36-h assay is used, this may permit the presentation of IGF-I to its receptor at a critical time during the cell cycle progression. Maintenance of a more optimal receptor number may also be attained with this type of experimental design since it has been shown that the addition of high concentrations of free IGF-I to cells may result in down regulation of receptors.

IGF-I mutants that have a reduced affinity for IGFBPs have also been used to illustrate this phenomenon. Specifically, in human fibroblasts, an IGF-I mutant that bound poorly to IGFBP-1 did not result in optimal stimulation of DNA synthesis compared to wild type IGF-I [110]. Similarly, insulin which does not bind to IGF binding proteins cannot mimic the full effect of IGF-I in many cell culture systems, even though it will achieve the same percentage binding to receptors and the same degree of receptor activation of receptor tyrosine kinase if added in high enough concentration. This suggests that some other effect of the IGF/IGFBP complex is required during DNA synthesis assays for optimal responsiveness. Koistinen et al. confirmed these findings in dermal fibroblasts, showing the IGF-I to IGFBP-1 molar ratios between $2: 1$ and 25:1 resulted in an increase in the ${ }^{3} \mathrm{H}$ thymidine incorporation response [111].

Kratz et al. showed that an equimolar or higher ratio was used, that IGFBP-1 also enhanced the response of keratinocytes to IGF-I and that IGFBP-1 added alone had no effect [112]. The phosphorylation state of IGFBP has been shown to be important since phosphorylated IGFBP-1 resulted in significant inhibition of the ability of human fibroblasts to respond to IGF-I with increased DNA synthesis, whereas dephosphorylated IGFBP-1 resulted in potentiation in the same system [109].

\section{In vivo studies}

Although in vivo studies showing the potentiation of IGF action are limited, several wound-healing studies have shown that IGFBP-1 has a potentiation activity. Jyuan et al. reported that application of non- phosphorylated recombinant IGFBP-1 with IGF-I to skin incisions in rats showed an enhancement of woundbreaking strength by $33-40 \%$ if a molar ratio of IGF-I to IGFBP-1 of $4: 1$ or greater was used [113]. In contrast, if phosphorylated IGFBP-1 was utilized, there was no potentiating effect. Frost and Tang showed that the endometrial stromal cell response to medroxyprogesterone which induces luteinization and increases the secretion of phosphorylated IGFBP-1 is associated with growth attenuation [114]. In contrast, the proliferative phase endometrium is associated with the secretion of nonphosphorylated IGFBP-1. This suggests that the phosphorylation state of IGFBP-1 may be important for local control of IGF action.

More recently, Tsouboi et al. have reported that IGFBP-1 enhances the effects of IGF-I in promoting healing of dermal ulcers in both normal rabbits and in rabbits with diabetes. The rate of re-epithelization and granulation tissue formation was stimulated, compared to control animals that received IGF-I alone when an IGF-I to nonphosphorylated IGFBP-1 ratio of $3: 1$ was used [115]. To date, no transgenic animals have been prepared with the mutant form IGFBP-1 that is nonphosphorylated to determine if hypersecretion of this form can accelerate growth.

\section{IGF-independent actions}

As pointed out previously, IGFBP-1 contains an RGD sequence and binds to the $\alpha 5 \beta 1$ integrin $[59,116]$. The functional significance of this interaction was shown by transfecting the IGFBP-1 cDNA into CHO cells. The cells that were expressing high concentrations of IGFBP1 migrated much more rapidly than cells that were transfected with vector alone. In addition, exogenous addition of pure IGFBP-1 to control cells resulted in enhanced migration. Since there was no response to IGF-I, this appeared to be a direct effect of IGFBP-1. To determine that the RGD sequence was required and that the interaction was with the $\alpha 5 \beta 1$ receptor, the cells were transfected with a mutant IGFBP-1 that contained a single substitution in amino acid position 221 converting the arginine to tryptophan. The cells that were transfected did not show any increase in their rate of migration. 
Similarly, exogenously added $\left[\operatorname{Tr}^{221}\right]$ IGFBP-1 did not stimulate migration of nontransfected cells.

Unlike IGFBP-1, we were not able to demonstrate that the $\alpha 5 \beta 1$ integrin could bind to IGFBP-2. In contrast to this observation, Dehanty et al. have demonstrated that IGF-potentiating activity can be demonstrated by IGFBP-2 and that this effect is lost when the RGD sequence is modified in IGFBP-2 [117]. The integrin that mediates this effect has not been determined.

\section{IGFBP-2}

\section{Inhibitory actions}

IGFBP-2 concentrations in serum are induced by IGF$\mathrm{I}$ and inhibited by $\mathrm{GH}$; therefore, its role in controlling IGF action is an important subject of analysis. Purified IGFBP-2 has been shown to inhibit DNA synthesis in chick embryo fibroblasts and rat astroglial cells $[36,118]$. It is also an important inhibitor of IGF-II stimulated DNA synthesis in lung carcinoma cells. This inhibition is believed to occur by inhibition of IGF binding the receptor since it inhibits binding to MDBK cells [119]. Des-IGF-I does not bind to IGFBP-2 and stimulates DNA synthesis in MDBK cells. Its effect exceeds that of IGF-II, suggesting that IGFBP-2 is inhibiting this response. IGFBP-2 has also been shown to inhibit other functions of IGF-I, such as inhibition of protein breakdown [119]. IGFBP-2 could inhibit completely the effect of IGF-I stimulating smooth muscle cells to migrate [116]. IGF-I stimulated collagen synthesis has been shown to be inhibited by IGFBP-2 [120].

\section{Stimulatory effects}

In spite of these reports of inhibition, several paradoxical observations have been noted. First, when IGFI is administered to experimental animals, there is a large increase in IGFBP-2, suggesting that it may not always be inhibiting IGF action. Second, gene knockout animals in whom IGFBP-2 has been deleted have small spleens compared to control animals, suggesting that the known effect of IGF-I on inducing splenic enlargement in normal animals may be due, in part, to enhanced expression of IGFBP-2 [121]. In vitro, Bar et al. showed that partially purified IGFBP-2 enhanced the effect of IGF-I on glucose transport and AIB uptake in microvascular epithelial cells [122]. Whether this is a direct effect of IGFBP-2 or IGF-I bound to IGFBP-2 was not determined. Bovine IGFBP-2 was also shown to potentiate the replication response to IGF-I by smooth muscle cells by approximately $80 \%$ [123]

\section{IGFBP-3}

\section{Inhibition of IGF action}

Because of its role of carrying IGFs in serum, IGFBP-3 has been an important focus of modulating the endocrine actions of IGF-I. The addition of excess purified IGFBP3 with IGF-I inhibits the insulin-like actions of IGF-I in $\mathrm{Balb} / \mathrm{c}$ 3T3 cells [102]. The addition of excess IGFBP3 to cultured fibroblasts inhibits their DNA synthesis response to IGF-I with maximum inhibition noted at a $4: 1$ molar ratio of IGFBP-3 to IGF-I [124]. IGFBP-3 has also been shown in chick fibroblasts to inhibit IGFI-stimulated DNA synthesis, and it also inhibits the effect of FGF on these cells, suggesting that it may have IGFindependent actions [125]. IGFBP-3 has been noted to inhibit IGF-I-stimulated steroidogenesis in rat granulosa cells and to inhibit cyclic AMP generation by IGF-I [126]. It also inhibits collagen synthesis in cultured rat osteoblasts or mouse osteoblasts [127]. Although it inhibits IGF-stimulated glucose uptake in porcine fat cells, it has no effect on insulin-stimulated uptake.

\section{Potentiation of IGF action}

Demello and Baxter first reported that, if IGFBP-3 was associated with cell surfaces, it could stimulate DNA synthesis in human fibroblasts [65]. Pre-incubation of the cultures with IGFBP-3 prior to IGF-I addition was required. Conover extended these observations to determine that, when IGFBP-3 was coincubated with increasing concentrations of IGF-I, there was a dose-dependent increase in AIB uptake [100]. She has proposed that proteolysis of IGFBP-3 or processing of the molecule on the cell surface may be required for this response. Conover has shown that IGF receptor down-regulation is prevented by preincubation of IGFBP-3, and this may be one mechanism whereby it enhances the effects of IGF1. Similarly, Ernst and Rodan reported that cell surfaceassociated IGFBP-3 could potentiate the effect of IGF-I and AIB uptake in rat osteoblasts [128]. Blum confirmed these observations, showing that coincubating IGF-I with IGFBP-3 results in a $90 \%$ increase in DNA synthesis in BHK cells [129]. Proteolysis of IGFBP-3 also may be important. Schmidt et al. have shown that the 30-kDa fragment of IGFBP-3 that is generated by a protease results in potentiation of the effect of IGF-I on osteoblast DNA synthesis [126].

Administration of IGFBP-3 and IGF-1 to rat wounds results in accelerated healing [130]. The combination of IGFBP-3 and IGF-I is anti-catabolic and functions better than administration of IGF-I alone to GH deficient rats [131]. The studies of Bagi $e t$ al. have shown that administration of IGF-I plus IGFBP-3 to oophorectomized rats results in the stimulation of growth and an increase in bone mineral density [132]. This increase is dependent upon dose and equimolar administration of IGF-I and IGFBP-3. Stewart et al. have shown that a polyclonal antibody to IGF-I that functions similarly to IGFBP3 in prolonging IGF half-life in plasma results in the potentiation of IGF-I-stimulated growth in hypophysectomized rats [133]. In contrast, in Snell dwarf mice. administration of a molar excess of IGFBP-3 with IGFI results in the inhibition of the IGF-I-stimulated growth 
response [134]. Administration of an IGF analog to pigs that binds poorly to IGFBP-3 did not result in growth stimulation. Interestingly, overexpression of IGFBP-3 in tissues also may enhance the effects of IGF-I. IGFBP-3 transgenic animals show visceral tissue enlargement. IGF-I is known to be anti-apoptotic to breast epithelial cells. Transfection of breast epithelium with a tissuespecific IGFBP-3 promoter resulted in inhibition of the normal involution that occurs when rat pups are withdrawn during lactation [135]. This suggests, but does not prove, that IGFBP-3 is acting locally to potentiate the effects of IGF-I in inhibiting apoptosis.

\section{IGF independent effects}

Direct effects of IGFBP-3 on cell growth have also been reported. Transfection of Balb/c3T3 cells with IGFBP3 cDNA results in inhibition of their DNA synthesis independently of IGF-I. IGFBP-3 has also been shown to attenuate the effects of FSH on granulosa cell function directly and to inhibit the response of mouse embryo fibroblasts to serum or FGF $[124,136]$. More recently, the inhibitory effects of TGF- $\beta$ on breast carcinoma cell division have been shown to be mediated through an induction of IGFBP-3. Oh et al. have shown that addition of IGFBP-3 or truncated fragments that do not bind to IGF-I to HS578T human breast cancer cells results in the inhibition of DNA synthesis independently of its effects on IGF-I actions [137]. These investigators have purified a group of cell surface proteins that bind to IGFBP-3 and have preliminary reported amino acid sequence data, suggesting that IGFBP-3 may have its own receptor on the cell surface, which mediates these actions [138].

\section{IGFBP-4}

IGFBP-4 is the only form of IGF binding protein that has been shown to consistently inhibit IGF-I action. Although there is minimal IGFBP-4 in serum, substantial concentrations may exist in some pericellular fluids. IGFBP-4 does not have any of the properties associated with lowering of IGFBP affinity, such as cell surface association or dephosphorylation. It does undergo proteolytic cleavage, and the fragments do not bind IGF-I or -II.

Mohan et al. originally showed IGFBP-4's ability to inhibit the effect of IGF-I on chick pelvic cartilage growth [139]. Inhibition was does-dependent and required a molar excess of IGFBP-4. Similarly, Ui et al. showed that IGFBP-4 could inhibit steroidogenesis in rat granulosa cells [140], and Coulouscou et al. showed its ability to inhibit DNA synthesis in HD-29 colon carcinoma cells [141]. Other IGF-I stimulated differentiated functions that have been shown to be inhibited are cyclic AMP generation in osteoblasts, protein synthesis in B104 cells, glycogen synthesis in osteosarcoma cells and steroidogenesis in granulosa cells in response to FSH [142]. It is also a potent inhibitor of IGF-I-stimulated DNA synthesis in smooth muscle cells [143]. Proteolytic cleavage of IGFBP-4 is an important post-translational modification. Fibroblasts and smooth muscle cells have been shown to release IGFBP-4 proteases [143, 144]. Following proteolytic cleavage, there is an increase in the AIB uptake or DNA synthesis responses to IGF-I in these test systems. The proteolytic cleavage site in rat IGFBP-4 has been identified and is between residues K120 and H121 [61]. There is also a secondary site between residues M131 and K132 [145]. Mutagenesis of these cleavage sites with readdition of a mutant that is resistant to proteolysis shows that the protease-resistant mutant is more active in inhibiting IGF-I action. No in vivo studies of IGFBP-4 action have been reported to date. In summary, IGFBP-4's main role is to protect cells from over-stimulation by the IGFs and possibly to accelerate their clearance.

\section{IGFBP-5}

\section{Inhibition of IGF action}

Addition of molar excess of IGFBP-5 to cell lines that do not secrete IGFBP-5 protease generally results in inhibition of IGF actions. Keifer et al. showed that IGFBP5 can inhibit IGF-I stimulation of DNA and glycogen synthesis in human osteosarcoma cells [146]. Wang et al. showed inhibition of steroidogenesis in granulosa cells [147].

\section{Potentiation of IGF activity}

Multiple investigators have reported stimulation of IGF action. When IGFBP-5 is allowed to associate with fibroblast ECM, and then fibroblasts are replated on top of this matrix, it can result in a two-fold enhancement of IGF action [66]. Since the affinity of IGFBP-5 for IGF-I is lowered eight-fold after ECM association, and the IGFbound IGFBP-5 is in a more favorable equilibrium with receptors, this affinity shift presumably accounts for this effect. Bautista et al. have shown that IGFBP-5 potentiated the effect of IGF-I on osteoblast growth and protein synthesis [148]. Andress et al. also reported this effect for osteoblasts and have shown that a 22-kDa IGFBP-5 fragment that is generated by proteolysis also directly stimulates DNA synthesis in these cells independently of IGF-I [149]. Whether this fragment is binding to a unique receptor is unknown; however, they have reported a 300$\mathrm{kDa}$ protein present on the surface of these cells that binds to IGFBP-5 and the 22-kDa fragment [150]. Conover has reported data that IGF-I binding to IGFBP-5 inhibits proteolysis of binding protein, although the need for proteolysis of IGFBP-5 for potentiation of IGF-I DNA stimulated synthesis has not been definitively established [151].

Since the ability of IGFBP-5 to potentiate IGF action on smooth muscle cells, fibroblasts or osteoblasts results from its ability to bind to ECM, understanding the factors in ECM and the regions of IGFBP-5 that are necessary for ECM association is important. Proteoglycans are 
a major component of the ECM that binds to IGFBP-5. Glycosaminoglycans, such as heparin and heparan sulfate, bind to IGFBP-5, whereas chondroitin sulfate $A$ and $C$ have no activity [100]. This suggests that the glycosaminoglycan structure that is necessary for this binding is conferred by $\mathrm{O}$-sulfation of the 2 and 3 positions of the iduronic acid ring. The region between amino acids 201 and 218 in IGFBP-5 contains 10 out of 18 amino acids that are basic. Competitive binding studies with peptides and mutants have shown that this region contains the GAG binding domain that is required for ECM association [152]. Mutagenesis of key residues in this area, principally amino acids 207,214 and 218 , results in nearly complete loss of its affinity for either glycosaminoglycan of ECM [152, 153]. Proteoglycans often bind to basic residues and, therefore, may be the principle ECM binding component. IGFBP-5 also binds to ECM by binding plasminogen activator inhibitor-I and vitronectin. Association of the PAI-I vitronectin complex with IGFBP-5 maybe an important mechanism for its stabilization within ECM.

\section{IGFBP-6}

In vivo studies of IGFBP-6 are quite limited. It may have an anti-gonadotropin effect in the ovaries since it inhibits effects of FSH and LH combined in the steroidogenesis response to IGF-I. In addition, it has been shown in bone that IGFBP-6 is regulated rather uniquely, which suggests that it may be an important modulator of IGF-II action in this tissue.

\section{SUMMARY}

The IGF-binding proteins are important modulators of IGF action. They function to control the half-life of IGF-I and -II in blood, their distribution among tissues and extracellular fluids and, most importantly, the ability of IGF-I or IGF-II to associate with cell surface receptors. Since equilibrium in extracellular fluids almost always favors binding to the IGFBPs as opposed to the IGF receptors, these proteins function as important modulators of IGF action. Variables that alter their affinity, such as proteolysis, adherence to cell surfaces or extracellular matrix and phosphorylation, may be an important means for controlling the release of IGF to receptors. Since the concentrations in these proteins and extracellular fluids may be regulated either coordinately or independently of the factors that regulate the IGFs, this provides an important additional level of control of the degree of exposure of cells to this potent mitogen.

In spite of much in vitro evidence to support these conclusions, in vivo experiments, using transgenic or gene targeting techniques, are only beginning to emerge. This will be an important area for future investigation.

\section{REFERENCES}

1. Zapf J, Waldvogel M, Froesch ER. Binding of nonsuppressible insulin-like activity to human serum: Evi- dence for a carrier protein. Arch Biochem Biophys 1975 , 168, 638-645.

2. Hintz RL, Liu F. Demonstration of specific plasma protein binding sites for somatomedin. J Clin Endocr Metah 1977, 45, 988-995.

3. Furlanetto RW. Somatomedin binding protein: Evidence for heterogenous subunit structure. J Clin Endocr Metah $1980,51,12-19$.

4. Drop SLS, Kortleve DJ, Guyda HJ. Isolation of a somatomedin-binding protein from preterm amniotic fluid. Development of a radioimmunoassay. $J$ Clin Endocr Metab 1984, 59, 899-907.

5. Povoa G, Enberg G, Jornvall H. Hall K. Isolation and characterization of a somatomedin binding protein from mid term human amniotic fluid. Eur J Biochem 1984, 144, 199-204.

6. Brewer MT, Stetler GL, Squires CH, Thompson RC, Busby WH, Clemmons DR. Cloning, characterization and expression of a human insulin-like growth factor binding protein. Biochem Biophys Res Commun 1988, 152, 12891297.

7. Lee YL, Hintz RL, James DM, Lee PDK, Shively JE, Powell DR. Insulin like growth factor IGF binding protein complementary deoxyribonucleic acid from human Hep G2 hepatoma cells: predicted protein sequence suggests and IGF binding domain different from those of IGF-I and IGF-II receptors. Molec Endocr 1988, 3, 404-411.

8. Brown AL. Chiariotti L. Orlowski CC, et al. Nucleotide sequence and expression of a cDNA clone encoding a fetal rat binding protein for insulin-like growth factors. $J$ Biol Chem 1989, 264, 5148-5154.

9. Martin JL, Baxter RC. Insulin like growth factor binding protein from human plasma, purification and characterization. I Biol Chem 1986, 261, 8754-8760.

10. Wood, WI, Cachianes G, Henzel WJ, et al. Cloning and expression of the $\mathrm{GH}$ dependent insulin like growth factor binding protein. Molec Endocr 1988, 2, 1176-1185.

11. Shimasaki S, Shimonaka M, Zhang HP, Ling N. Identification of five different insulin-like growth factor binding proteins (IGFBPs) from adult rat serum and molecular cloning of a novel IGFBP in rat and human. I Biol Chem 1991, 266, 10,646-10,653.

12. Drop SLS, Kortleve DJ, Guyda HJ, Posner BI. Immunoassay of a somatomedin-binding protein from human amniotic fluid: levels in fetal, neonatal, and adult sera. $J$ Clin Endocr Metab 1984, 59, 908-915.

13. Baxter RC. Martin, JL. Radioimmunoassay of growth hormone dependent insulin-like growth factor binding protein in human plasma. J Clin Intest 1986, 78, 1504 1512.

14. Baxter RC. Physiological roles of the IGF binding proteins, In Spencer EM ed. Modem Concepts of Insulinlike Growth Factors. New York, Elsevier, 1991, 371-380.

15. Streck RD, Wood TL, Hsu MS, Pintar JE. Insulin-like growth factor I and II and insulin-like growth factor binding protien-2 mRNAs are expressed in adjacent tissues within rat embryonic and fetal limbs. Der Biol 1992, 151, $586-596$.

16. Jennische E, Skottner A, Hansson HA. Dynamic changes in insulin-like growth factor I immunoreactivity correlate with repair events in rat ear after freeze-thaw injury. Exp Molec Pathol 1987, 47, 193-201.

17. Behringer RR, Lewin TM, Quaife CJ, Palmiter RD, Brinstre RL, D`Ercole AJ. Expression of insulin-like growth factor I stimulates normal somatic growth in growth hormone deficient transgenic mice. Endocrimology 1990, 127, $1033-1040$.

18. DeChiara RM, Efstratiadis A, Robertson EJ. A growth deficiency phenotype in heterozygous mice carrying an insulin-like growth factor II gene disruption. Nature 1990. 345, $78-80$ 
19. Liu JP, Baker J, Perkins AS, Robertson EJ, Efstratiadis A. Mice carrying small mutations of the genes encoding insulin like growth factor I (IGF-I) and type 1 IGF receptor (IGF/r). Cell 1993, 75, 73-82.

20. Camacho-Hubner C, Busby WH, McCusker RH, Wright $\mathrm{G}$, Clemmons DR. Identification of the forms of insulinlike growth factor binding proteins produced by human fibroblasts and the mechanisms that regulate their secretion. J Biol Chem 1992, 267, 11,949-11,956.

21. Cerro JA, Grewal A, Wood TL, Pintar JE. Tissue-specific expression of insulin-like growth factor binding protein (IGFBP) mRNAs in mouse and rat development. Regul Peptide 1993, 48, 189-198.

22. Rechler MM. Insulin like growth factor binding proteins. Vitamins and Hormones 1993, 47, 1-114.

23. Hossenlopp P, Seurin D, Segovia B, Portolan G, Binoux M. Heterogeneity of insulin-like growth factor binding proteins and relationships between structure and affinity. 2. Forms released by human and rat liver in culture. Eur $J$ Biochem 1987, 170, 133-142.

24. Unterman TG, Oehler DT, Murphy LJ, Lacson RG. Multihormonal regulation of insulin like growth factor binding protein-1 in rat $\mathrm{H} 4$ IIE hepatoma cells: the dominant role of insulin. Endocrinology 1991, 128, 2693-2701.

25. Ooi GT, Tseng LY, Tran MQ, Rechler MM. Insulin rapidly decreases insulin-like growth factor-binding protein1 gene transcription in streptozoticin-diabetic rats. Molec Endocr 1992, 6, 2219-2228.

26. Swanichkul A, Allander SV, Morris SL, Powell DR. Glucorticoids and insulin regulate expression of the human gene for insulin like growth factor binding protein-1 through proximal promoter elements. Proc Natl Acad Sci USA 1994, 269, 30,835-30,841.

27. Strauss DS, Takemoto CD. Effect of fasting on insulinlike growth factor-I (IGF-I) and growth hormone receptor mRNA levels and IGF-1 gene transcription in rat liver. Molec Endocr 1990, 4, 91-100.

28. Adamo ML, Shao ZM, Lanau F, et al. Insulin like growth factor I (IGF-I) and retinoic acid modulation of IGF binding proteins (IGFBPs). IGFBP-2, 3 and 4 gene expression and protein secretion in a breast cancer cell line. Endocrinology 1992, 131, 1858-1866.

29. Wood TL, Brown AL, Rechler MM, Pintar JE. The expression pattern of an insulin like growth factor (IGF) binding protein gene is distinct from IGF-II in mid gestation embryo. Molec Endocr 1990, 4, 1257-1263.

30. Wood TL, Rogler L, Pintar JE. Targeted gene disruption of the IGFBP-2 gene. Growth Regul 1993, 3, 5-8.

31. Adamo ML, Bach MA, Roberts CT, LeRoith D. Regulation of insulin IGF-I and IGF-II gene expression. In LeRoith D ed. Insulin-like Growth Factors: Molecular and Cellular Aspects. Boca Raton, FL, CRC Press, 1990, 271303.

32. Walker JL, Ginalska-Malinowska M, Romer TC, Pucilowska JB, Underwood LE. Effects of infusion of insulinlike growth factor-I in a child with growth hormone insensitivity syndrome. $N$ Engl J Med 1991, 324, 1483-1488.

33. Baxter RC, Martin JL. Binding proteins for insulin-like growth factors: structure, regulation and function. Progr Growth Fact Res 1989, 1, 49-68.

34. Takenada A, Miura Y, Mori A, Hirosawa M, Kato H, Noguchi T. Distribution of $m$ RNAs of insulin-like growth factor binding proteins 1 and 3 between parenchymal and non-parenchymal cells in the liver. J Biol Chem 1991, 55, 1191-1193.

35. Booth BA, Bar RS, Boes M, Dake BL, Bayne ML, Cascieri MA. Intrinsic bioactivity of insulin-like growth factor binding proteins from endothelial cells. Endocrinology 1990, 6127, 2630-2638.

36. Rechler MM, Nissley SP. Insulin-like growth factors. In
Peptide Growth Factors and Their Receptors. Berlin, Springer, 1993, 263-287.

37. Baxter RC, Martin JL. Structure of the $M_{\mathrm{T}} 140,000$ growth hormone-dependent insulin-like growth factor binding protein complex: determination by reconstitution and affinity labeling. Proc Natl Acad Sci USA 1989, 86, 6898-6902.

38. Guler H-P, Zapf J, Schmid C, Froesch ER. Insulin-like growth factors I and II in healthy man. Estimations of half-lives and production rates. Acta Endocr 1989, 121, 753-758.

39. Dai J, Baxter RC. Regulation of acid labile subunit of the rat serum insulin-like growth factor binding protein complex. Endocrinology 1994, 135, 1066-1072.

40. Hodgkinson SC, Davis SR, Moore LG, Henderson HV, Gluckman PD. Metabolic clearance of insulin-like growth factor-II in sheep. $J$ Endocr $1989,123,461-468$.

41. Dai J, Baxter RC. Regulation in vivo of acid labile subunit of the rat serum insulin like growth factor binding protein complex. Endocrinology 1994, 135, 2335-2341.

42. Zapf J, Schmid C, Guler HP, et al. Regulation of binding proteins for insulin-like growth factors in humans: Increased expression of IGF binding proteins during treatment of healthy adults and in patients with extrapancreatic tumor. $J$ Clin Invest 1990, 86, 952-961.

43. Camacho-Hubner C, Clemmons DR, D'Ercole AJ. Regulation of insulin-like growth factor binding proteins in transgenic mice with altered expression of growth hormone and IGF-I. Endocrinology 1991, 129, 1201-1206.

44. Daughaday WH, Kapadia M. Significance of abnormal serum binding of insulin-like growth factor II in the development of hypoglycemia in patients with non-islet cell tumors. Proc Natl Acad Sci USA 1989, 86, 6778-6782.

45. Boni-Schnetzler M, Binz K, Mary J-L, Schmid C, Schwander J, Froesch ER. Regulation of hepatic expression of IGF I and fetal IGF binding protein mRNA in streptozotocin-diabetic rats. Fedn Eur Biochem Socs Lett 1989, 251, 253-256.

46. Clemmons DR, Busby WH, Snyder DK. Variables controlling the secretion of insulin-like growth factor binding protein-2 in normal human subjects. $J$ Clin Endocr Metab 1991, 73, 727-733.

47. Straus DS, Takemoto CD. Effect of dietary protein deprivation insulin-like growth factor IGF-I and II, IGF binding protein- 2 and serum albumin gene expression in the rat. Endocrinology 1990, 127, 1849-1860.

48. Busby WH, Snyder DK, Clemmons DR. Radioimmunoassay of a 26,000 dalton plasma insulin like growth binding protein: control by nutritional variables. $J$ Clin Endocr Metab 1988, 67, 1225-1230.

49. Suwannichkul A, Allander SV, Morris SL, Powell DR. Glucocorticoids and insulin regulate expression of the human gene for insulin-like growth factor binding protein1 through proximal promoter elements. J Biol Chem 1996, 269, 30,835-30,841.

50. O'Brien RM, Lucas PC, Forest CD, Magneson $\mathrm{MH}$, Granner DK. Identification of the sequence in the PEPCK gene that mediates the systemic effect of insulin on transcription. Science 1990, 249, 533-537.

51. Bar RS, Boes M, Clemmons DR, et al. Insulin differentially alters transcapillary movement of intravascular IGFBP-1, IGFBP-2 and endothelial cell IGF binding proteins in rat heart. Endocrinology 1990, 127, 497-499.

52. Lewitt MS, Sanders H, Baxter RC. Bioavailability of insulin like growth factors (IGF's) in rats determined by molecular distribution of human IGF binding protein-3. Endocrinology 1993, 133, 1797-1802.

53. Senevirantre C, Jiangming L, Murphy LJ. Transcriptional regulation of rat insulin like growth factor binding protein-1 expression by growth hormone. Molec Endocr 1990, 4, 1199-1204 
54. Luo J, Murphy LJ. Dexamethasone inhibits growth hormone induction of insulin-like growth factor-I (IGF-I) messenger ribonucleic acid (mRNA) in hypophysectomized rats and reduces IGF-I mRNA abundance in the intact rat. Endocrinology 1989, 125, 165-171.

55. Ooi GT, Orlowski, CC, Brown AL, Becker RE, Unterman TG, Rechler MM. Different tissue distribution and hormonal regulation of messenger RNAs encoding rat insulin-like growth factor binding proteins- 1 and 2. Molec Endocr 1990, 4, 321-328.

56. O'Brien RM, Noisen RL, Sandwich L, et al. Hepatic membrane factor 3 and hormone regulated responsiveness of PEPCK and insulin-like growth factor binding protein-1 genes. Molec Cell Biol 1994, 203, 1835-1841.

57. Honda Y, Landale EC, Strong DD, Baylink DJ, Mohan S. Recombinant synthesis of insulin-like growth factor binding protein-4: Development of a radioimmunoassay for IGFBP-4 in human serum and other biological fluids. $J$ Clin Endocr Metab 1996, 81, 1389-1396.

58. Binoux M, Roghani M, Hassenlopp P, Harudin S, Gourmelen M. Molecular forms of human IGF binding proteins: Physiological implications. Acta Endocr 1991, 124 (Supp 2), 41-47.

59. Zapf J, Keifer MC, Merryweather J, et al. Isolation from adult human serum forms of insulin-like growth factor binding proteins and molecular cloning of one of them that is increased by IGF-I administration. $J$ Biol Chem 1990, 265, 14,892-14,898.

60. Jones JI, Gockerman A, Busby WH, Jr, Wright G, Clemmons DR. Insulin-like growth factor binding protein 1 stimulates cell migration and binds to the $\alpha 5 \beta 1$ integrin by means of its Arg-Gly-Asp sequence. Proc Natl Acad Sci USA 1993, 90, 10,553-10,557.

61. Chernausek SD, Smith CE, Duffin KL, Busby WH, Wright G, Clemmons DR. Proteolytic cleavage of insulin like growth factor binding protein-4 (IGFBP-4). $J$ Biol Chem 1995, 270, 11,377-11,382.

62. Jones JI, D'Ercole AJ, Camacho-Hubner C, Clemmons DR. Phosphorylation of insulin-like growth factor binding protein in cell culture and in vivo: effects on affinity for IGF-I. Proc Natl Acad Sci 1991, 88, 7481-7485.

63. Elgin RG, Busby WH, Clemmons DR. An insulin-like growth factor binding protein enhances the biologic response to IGF-I. Proc Natl Acad Sci USA 1987, 84, 3254-3258.

64. McCusker RH, Camacho-Hubner C, Bayne ML, Cascieri MA, Clemmons DR. Insulin-like growth factor (IGF) binding to human fibroblast and glioblastoma cells: The modulating effect of cell released IGF binding proteins (IGFBPs). J Cell Physiol 1990, 144, 244-253.

65. DeMellow JSM, Baxter RC. Growth hormone dependent insulin-like growth factor binding protein both inhibits and potentiates IGF-I stimulated DNA synthesis in skin fibroblasts. Biochem Biophys Res Commun 1988, 156, 199204

66. Jones JI, Gockerman A, Busby WH, Camacho-Hubner C, Clemmons DR. Extracellular matrix contains insulinlike growth factor binding protein-5: potentiation of the effects of IGF-I. $J$ Cell Biol 1993, 121, 679-687.

67. Clemmons DR, Underwood LE, Chatelain PG, Van Wyk $\mathrm{JJ}$. Liberation of immunoreactive somatomedin-C from its binding proteins by proteolytic enzymes and heparin. $J$ Clin Endocr Metab 1983, 56, 384-389.

68. Lassare C, Binoux M. Insulin-like growth factor binding protein-3 is functionally altered in pregnancy plasma. Endocrinology 1994, 134, 1254-1262.

69. Lee CY, Rechler MM. Proteolysis of insulin-like growth factor binding protein-3 in 150 kilodalton IGFBP complexes by a cation dependent protein activity in adult rat serum promotes the release of IGF-I. Endocrinology 1995, 136, $4982-4989$.
70. Hossenlopp P, Segovia B, Lassare C, Roghani M, Bredon M, Binoux M. Enzymatic evidence of degradation of insulin-like growth factor binding protein in $150 \mathrm{k}$ complex during pregnancy. J Clin Endocr Metab 1990, 71, 797805.

71. Guidice LC, Farrell EM, Pham H, Lamson FG, Rosenfeld $\mathrm{RG}$. Insulin like growth factor binding proteins in maternal serum throughout gestation and in the puerperium. J Clin Endocr Metab 1990, 71, 806-816.

72. Davenport ML, Clemmons DR, Miles MV, CamachoHubner C. D'Ercole AJ, Underwood LE. Regulation of serum insulin-like growth factor I (IGF-I) and IGF binding proteins during rat pregnancy. Endocrinologv 1990 , 127, 1278-1286.

73. Fowlkes J, Enghild JJ, Suzukik N, Nagase H. Matrix metalloproteases degrade insulin like growth factor binding protein-3 in dermal fibroblast cultures. $J$ Biol Chem 1994, 269, 25,742-25,746.

74. Bang P, Brismar K, Rosenfeld RG, Hall K. Fasting affects serum insulin-like growth factor (IGFs) and IGF binding proteins differently in patients with NIDDM versus nonobese and obese weight matched healthy subjects. $J$ C/m Endocr Metab 1994, 78, 960-966

75. Fielder PJ, Guevara-Aguirre J, Rosenbloom AL, Carlsson L. Hintz RL, Rosenfeld RG. Expression of insulin-like growth factors, IGF binding proteins and growth hormone binding proteins in heterozygous relatives of Ecuadorian GH receptor deficient patients. $J$ Clin Endocr Metab 1992, 74, 743-750.

76. Cwyfan-Hughes SC, Cotterill AM, Molloy AR. Induction of specific proteases for insulin-like growth factor binding protein following major heart surgery. J Endocr 1992, 135, $135-145$

77. Davenport ML, Isley WL, Pucilowska J. et al. Insulinlike growth factor binding protein-3 proteolysis is induced following elective surgery. J Clin Endocr Metab 1992, 130, 2505-2512

78. Blat C, Villaudy J, Binoux M. In vino proteolysis of serum insulin-like growth factor binding protein-3 results in minimal availability of IGF to target cells. $J$ Clin Incest 1994, 93, 2286-2290.

79. Cohen P, Graves HC, Peehl D, Kamasei M, Guidice LC, Rosenthal RG. Prostate specific antigen PSA is an insulinlike growth factor binding protein-3 protease found in seminal plasma 2. Clin Endocr Metab 1992, 75, 1046-1054.

80. Conover CA, DeLeon DD. Acid-activated insulin-like growth factor binding protein-3 proteolysis in normal and transformed cells: role of cathepsin-D. J Biol Chem 1994. 269, 7076-7080

81. Lalou C, Binoux M. Evidence that proteolysis of insulinlike growth factor binding protein-3 occurs in the normal state outside of the bloodstream. Regul Pept 1993, 48, 179-188.

82. Gargosky SE, Pham H. Wilson KF, Liu F, Guidice LC, Rosenfeld RG. Measurement and characterization of insulin-like growth factor binding protein-3 in human biologic fluids discrepancy between radioimmunoassays and ligang blotting. Endocrinology 1992, 131, 3051-3060.

83. Davenport ML, Pucilowska J, Clemmons DR, Lundblad $\mathrm{R}$, Spencer JA, Underwood LE. Tissue specific expression of IGFBP-3 protease activity during rat pregnancy. Endocrinology 1992, 75, 590-595.

84. McCusker RH, Campion DR, Jones WK, Clemmons DR. The insulin-like growth factor-binding proteins of porcine serum: endocrine and nutritional regulation. Endocrinology 1989, 125, 501-509.

85. Pucilowska JB, Davenport ML, Kabir I, et al. The effect of dietary protein supplementation on insulin like growth factors (IGF's) and IGF binding proteins in children with shigellosis. J Clin Endocr Metah 1993, 77, 1516-1521. 
86. Gockerman A, Clemmons DR. Porcine aortic smooth muscle cells secrete a serine protease for insulin like growth factor binding protein-2. Circ Res 1995, 76, 514-521.

87. Nam TJ, Busby WH, Clemmons DR. Human fibroblasts secrete a serine protease that cleaves insulin like growth factor binding protein-5. Endocrinology 1994, 135, 13851391.

88. Andress DL, Birnbaum RS. Human osteoblast-derived insulin-like growth factor (IGF) binding protein-5 stimulates osteoblast mitogenesis and potentiates IGF action. $J$ Biol Chem 1992, 267, 22,467-22,472.

89. Thrailkill KM, Quarles ID, Nagase H, Suzuki K, Serra DM, Fowlkes JL. Characterization of insulin-like growth binding protein-5 degrading proteases produced throughout murine osteoblast differentiation. Endocrinology 1995 , 136, 3527-3534.

90. Nam TJ, Busby WH, Jr, Clemmons DR. Characterization and determination of the relative abundance of two types of IGFBP-5 proteases that are secreted by human fibroblasts. Endocrinology in press.

91. Cheung PT, Wu J, Banach W, Chernausek S. Glucocorticoid regulation of insulin-like growth factor binding protein-4 protease by a rat neural cell line. Endocrinology 1994, 135, 798-806.

92. Hassager CL, Fitzpatrick LA, Spencer EM, Riggs FL, Conover CA. Basal and regulated secretion of insulin-like growth factor binding proteins in osteoblast-like cells is cell line specific. J Clin Endocr Metab 1992, 75, 228-233.

93. Parker A, Gockerman A, Busby WH, Clemmons DR. Properties of an insulin like growth factor binding protein 4 protease that is secreted by smooth muscle cells. Endocrinology 1995, 135, 2470-2476.

94. Durham SK, Keifer MR, Riggs BL, Conover CA. Regulation of insulin like growth factor binding protein-4 by a specific insulin like growth factor binding protein-4 protease in normal human osteoblast like cells. Implications on human cell physiology. J Bone Mineral Res 1994, 9, 111-117.

95. Jones JI, Busby WH, Wright G, Smith CE, Kimack NM, Clemmons DR. Identification of the sites of phosphorylation in insulin-like growth factor binding protein1: Regulation of its affinity by phosphorylation of serine 101. J Biol Chem 1993, 268, 1125-1131.

96. Ankrapp DP, Jones JI, Clemmons DR. Characterization of insulin like growth factor binding protein-1 kinases from human hepatoma cells. J Cell Biochem 1996, 60, 387399.

97. Westwood M, Gibson JM, White A. Purification and characterization of the IGFBP-1 phosphoform found in normal plasma. Presented to the 5th International Insulin and IGF Symposium. Abstract no. 14 1995, 3-5 March.

98. Hoeck WG, Mukku VR. Identification of the major sites of phosphorylation in IGF binding protein-3. J Cell Biochem 1994, 56, 262-273.

99. Baxter RC. Glycosaminoglycans inhibit formation of the $140 \mathrm{kDa}$ insulin like growth factor binding protein complex. Biochem J 1990, 271, 773-777.

100. Conover CA. Potentiation of insulin-like growth factor (IGF) action by IGF-binding protein-3: Studies of underlying mechanism. Endocrinology 1992, 130, 3191-3199.

101. Arai T, Parker AJ, Busby WH, Clemmons DR. Heparin, heparan sulfate, and dermatan sulfate regulate formation of the insulin-like growth factor-I and insulin-like growth factor-binding protein complexes. J Biol Chem 1994, 269, 20,388-20,393.

102. Ritvos O, Ranta T, Jalkanen J, et al. Insulin-like growth factor (IGF) binding protein from human decidua inhibits the binding and biological action of IGF-I in cultured choriocarcinoma cells. Endocrinology 1988, 122, 2150 2157.
03. Okajina $\mathrm{T}$, Iwashita $\mathrm{M}$, Takeda $\mathrm{Y}$, et al. Inhibitory effects insulin-like growth factor binding proteins 1 and 3 on IGF activated glucose consumption in mouse Balb/c3T3 fibroblasts. $J$ Endocr 1993, 133, 457-470.

104. Rutanen E-M, Pekonen F, Makinen T. Soluble $34 \mathrm{~K}$ binding protein inhibits the binding of insulin-like growth factor $I$ to its own well receptors in human secretory phase endometrium: evidence for autocrine/paracrine regulation of growth factor action. J Clin Endocr Metab 1988, 66, 173-180.

105. Frauman AG, Tsuzaki S, Moses AC. The binding characteristics and biological effects in FRTL 5 cells of placental protein-12, and insulin-like growth factor-binding protein purified from human amniotic fluid. Endocrinology 1989 , 124, 2289-2296.

106. Cox GN, McDermott MJ, Merkel E, et al. Recombinant human insulin-like growth factor binding protein-1 inhibits growth stimulated by IGF-I and growth hormone in hypophysectomized rats. Endocrinology 1994, 35, 19131920.

107. D'Ercole AJ, Dai Z, Xing Y, et al. Human insulin-like growth factor binding protein-1 (hIGFBP-1) transgenic mice: characterization and insights into the regulation of IGFBP-1 expression. Devl Brain Res 1994, 82, 213-222.

108. Rajkumar K, Barron D, Lewitt M, Murphy LJ. Growth retardation and hyperglycemia in insulin-like growth factor binding protein-1 transgenic mice. Endocrinology 1995 , 136, $4029-4034$.

109. Busby WH, Klapper DG, Clemmons DR. Purification of a 31000 dalton insulin-like growth factor binding protein from human amniotic fluid. $J$ Biol Chem 1988, 263, 14,203-14,210.

110. Clemmons DR, Cascieri MA, Camacho-Hubner C, McCusker RH, Bayne ML. Discrete alterations of the IGF-I molecule that alter its affinity for IGF binding proteins result in changes in bioactivity. $J$ Biol Chem 1990 , 265, 12,210-12,216.

111. Koistinen R, Itkinen P, Selenius P, Seppala M. Insulin like growth factor binding protein-1 inhibits binding of IGF-1 on fetal skin fibroblasts but stimulates their DNA synthesis. Biochem Biophys Res Commun 1990, 173, 408415 .

112. Kratz G, Lake M, Ljungstrom K, Forsberg G, Haegerstrand A, Gidlund M. Effect of recombinant IGF binding protein-1 on primary cultures of human keratinocytes and fibroblasts: selective enhancement of IGF-I but not IGF-II induced cell proliferation. Exp Cell Res 1992, 202, 381-385.

113. Jyung RW, Mustoe T, Busby WH, Clemmons DR. Increased wound breaking strength induced by insulinlike growth factor-1 in combination with IGF binding protein-1. Surgery 1994, 115, 223-239.

114. Frost JP, Tseng LT. Insulin-like growth factor binding protein-1 is phosphorylated by cultured human endometrial cells and multiple protein kinases in vitro. $J$ Biol Chem 1991, 266, 18,082-18,088.

115. Tsuboi R, Shi CM, Sato C, Cox GN, Ogawa H. Coadministration of insulin like growth factor (IGF-I) and IGF binding protein-1 stimulates wound healing in animal models. J Invest Dermatol 1995, 104, 199-203.

116. Gockerman A, Jones JI, Prevette T, Clemmons DR. Insulin like growth factor binding protein-2 inhibits smooth muscle cell migration response to IGF-I. Endocrinology 1995, 136, 41684173.

117. Delhanty PJD, Han VKM. An RGD to RGE mutation in the putative membrane binding domain of IGFBP-2 inhibits its potentiation of IGF-II induced thymidine uptake by SCP cell. Presented to the 75th Annual Meeting of the Endocrine Society. Las Vegas, NV. 1993, Abstract 2256 . 
118. Knauer DJ, Smith GL. Inhibition of biologic activity of multiplication stimulating activity by binding to its carrier protein. Proc Natl Acad Sci USA 1980, 77, 7252-7254.

119. Ross M, Francis GL, Szabo L, Wallace JC, Ballard FJ. Insulin-like growth factor (IGF)-binding proteins inhibit the biological activities of IGF-I and IGF-2 but not des(1-3)-IGF-I. Biochem $J$ 1989, 258, 267-272.

120. Feyen JH, Evans DB, Binkert C, Heinrich GF, Gaisse S, Koeher HP. Recombinant human CYS 281 insulin like growth factor binding protein-2 inhibits both basal and insulin like growth factor I stimulated proliferation and collagen synthesis in fetal rat calvaria. J Biol Chem 1991, 266, 19.469-19,474.

121. Pintar JE, Schuller A, Cerro JA, Czick M, Grewal A, Green B. Genetic ablation of IGFBP-2 suggests functional redundancy in the IGFBP family. Progr Growth Fact Res $1995,6,437-445$

122. Bar RS, Booth BA, Bowes M, Drake BL. Insulin-like growth factor binding proteins from cultured endothelial cells: Purification, characterization, and intrinsic biologic activities. Endocrinology 1989, 125, 1910-1920.

123. Bourner MJ, Busby WH, Siegel NR, Krivi GG, McCusker $\mathrm{RH}$, Clemmons DR. Cloning and sequence determination of bovine insulin-like growth factor binding protein-2 (IGFBP-2): comparison of it structural and functional properties with IGFBP-1. J Cell Biochem 1992, 48, 215 226.

124. Blat C, Delbe J, Villaudy J, Chatelain PG, Golde A, Harel L. Inhibitory diffusible factor- 45 bifunctional activity as a cell growth inhibitor and as an insulin-like growth factor I-binding protein. $J$ Biol Chem 1989, 264, 12,449-12,454.

125. Villaudy J, Delbe J, Blat C. Desaulty G, Gole A, Harel L. An IGF binding protein is an inhibitor of IGF stimulation. J Cell Physiol 1991, 149, 492-496.

126. Bicsak TA. Shimonaka M, Malkowski M, Ling N. Insulin-like growth factor binding protein-3 inhibition of granulosa cell function effect on cycle $3^{\prime} 5^{\prime}$ monophosphate. deoxyribonucleic acid synthesis and comparison of effect of IGF-I antibody. Endocrinology 1990, 126, $2184-2189$.

127. Schmid C, Rutishauser J, Schlapfer I, Froesch ER, Zapf J Intact but not truncated insulin-like growth factor binding protein-3 blocks IGF-I induced stimulation of osteoblasts: control of IGF signalling to bone cells by IGFBP-3 specific proteolysis. Biochem Biophys Res Commun 1991, 179, 579 . 585.

128. Earnst M. Rodan GA. Increased activity of IGF-I osteoblastic cells in the presence of $\mathrm{GH}$ : positive correlation with the presence of GH induced IGFBP-3. Endocrinology $1990,127,807-814$.

129. Blum WF, Jenne EW, Reppin F, Kietzmann K, Ranke MB, Bierich JR. Insulin-like growth factor I (IGF-I) binding protein complex is a better mitogen than free IGF-I Endocrinology 1989, 125, 766-772.

130. Sommer A, Maceck C, Spratt KS, et al. Molecular genetics and actions of recombinant insulin like growth factor binding protein-3. In Modern Concepts of Insulin-like Growth Factors. New York, Elsevier, 1991, 715-728.

131. Clark PG. Mortensen D, Reigsupreder D, Mohler M, Etchevery T, Mukkev V. Recombinant human insulin like growth factor binding protein 3 : Effects on the glycine and growth promotions activities of rh IGF-I in the rat. Grovth Regul 1993, 3, 46-50.

132. Bagi CM, Brommage R, Adams SO, Rosen DM, Sommer A. Benefit of systemically administered rh IGF-I and rh IGF-I IGBP-3 on cancellous bone in oophorectomized rats. J Bone Mineral Res 1994, 9, 1301-1312.

133. Stewart CH, Bates DC, Calder TA, Woddell SM, Pell JM Potentiation of insulin like growth factor (IGF-I) activity by an antibody: supportive evidence for enhancement of IGF-I bioavailability in vivo by IGF binding proteins. Endocrinolog. 1993, 133, 1462-1465.
134. van Buul-Offers SC, Reijen-Gresnigt R, Bloenen R, Hoogerbrugge $\mathrm{C}$, van den Brande JL. Co-administration of IGF-I binding protein-3 differentially inhibits IGF-I induced total body organ growth of Snell dwarf mice. Progr Growth Fact Res 1995, 6, 377-383.

135. Neuschwander S, Schwartz A, Wood TL, Roberts C. Henninghauser L, LeRoith D. Involution of the lactating mammary gland is inhibited by the IGF system in a transgenic mouse model. $J$ Clin Invest 1996, 97, 2225-2232.

136. Liu L, Delbe J, Blat C, Zapf J, Harel L. Insulin-like growth factor protein-3 (IGFBP-3) is an inhibition of serum growth factors other than IGF-I and IGF-II. J Cell Physiol 1992, 153, 15-21.

137. Oh Y, Muller HL, Lamson G, Rosenfeld RG. Insulin like growth factor (IGF) independent actions of IGF binding protein-3 in HS578 in human breast carcinoma cells. $J$ Biol Chem 1993, 268, 14,964-14,971.

138. Oh Y, Muller HL, Pham H, Rosenfeld RG. Demonstration of receptors of insulin-like growth factor binding protein-3 on HS578T breast cancer cells. $J$ Biol Chem 1996, 268, 26,045-26,048.

139. Mohan S, Bautista CM, Wergedal J, Baylink DJ. Isolation of inhibitory insulin-like growth factor (IGF) binding protein from bone cell conditioned medium: a potential local regulator of IGF action. Proc Natl Acad Sci USA 1989. 86, 8338-8342

140. Ui M, Shimonaka M, Shimasaki S, Ling N. An insulinlike growth factor-binding protein in ovarian follicular fluid blocks follicle-stimulating hormone-stimulated steroid production by ovarian granulosa cells. Endocrinology $1989, \mathbf{1 2 5}, 912-916$.

141. Coulouscou JM, Shoyab M. Purification of a colon cancer cell growth inhibitor and its identification as insulin-like growth factor binding protein-4. Cancer Res 1991, 51, 2813-2819.

142. Jones JI, Clemmons DR. Insulin like growth factor and their binding proteins: biologic actions. Endocr Rev 1995. 16, 3-34.

143. Cohick WS, Gockerman A, Clemmons DR. Vascular smooth muscle cells synthesize two forms of insulin-like growth factor binding proteins which are regulated differently by the insulin like growth factors. $J$ Cell Physiol $1993,157,52-60$.

144. Conover CA, Keifer MC, Zapf J. Post translational regulation of insulin like growth factor binding protein 4 in normal and transformed human fibroblasts. $J$ Clin Invest $1993,91,1129-1137$.

145. Conover CA, Durham SK, Zapf J, Masiarz FR, Keifer MC. Cleavage analysis of insulin-like growth factor (IGF)-dependent IGF-binding protein-4 proteolysis and expression of protease-resistant IGF-binding protein-4 mutants. J Biol Chem 1995, 270, 4395-4400.

146. Keifer MC. Schmid C. Waldvogel M, et al. Characterization of recombinant human insulin-like growth factor binding proteins $-4,-5$, and -6 produced in yeast. $J$ Biol Chem 1992. 267, 12,692-12,699.

147. Ling NC. Liu XJ, Malkowski M, Guo YL, Erickson GF, Shimasaki S. Structural and functional studies of insulinlike growth factor binding proteins in the ovary. Growth Regul 1993, 3, 70-74.

148. Bautista CM, Baylink DJ, Mohan S. Isolation of a novel insulin-like growth factor (IGF) binding protein from human bone: a potential candidate for fixing IGF-II in human bone. Biochem Biophy's Res Commun 1991, 176, 756-763.

149. Andress DL, Loop SM, Zapf J. Kiefer MC. Carboxy truncated insulin like-growth factor binding protein-5 stimulates mitogenesis in osteoblast like cells. Biochem Biophys Res Commun 1993, 195, 25-30.

150. Andress DL. Heparin modulates the binding of insu- 
lin/like growth factor (IGF) binding protein 5 to a membrane protein in osteoblastic cells. J Biol Chem 1995, 270, 28,289-28,296.

151. Conover CA, Keifer MC. Regulation of biological effect of endogenous insulin like growth factor binding protein 5 in human osteoblast cells. J Clin Endocr Metab 1993, 76, 1153-1159.

152. Arai T, Clarke S, Parker A, Busby WH, Clemmons DR.
Effect of substitution of specific amino acids in insulin like growth factor binding protein-5 on heparin binding and its change in affinity for IGF-I in response to heparin. $J$ Biol Chem 1996, 271, 6099-6106.

153. Parker A, Busby WH, Clemmons DR. Identification of the extracellular matrix bonding site for insulin like growth factor binding protein-5. J Biol Chem 1996, 271, $13,523-13,529$. 